\title{
Position effect variegation in Drosophila is associated with an altered chromatin structure
}

\author{
Lori L. Wallrath ${ }^{1}$ and Sarah C.R. Elgin \\ Department of Biology, Washington University, St. Louis, Missouri 63130 USA
}

\begin{abstract}
A euchromatic gene placed in the vicinity of heterochromatin by a chromosomal rearrangement generally exhibits position effect variegation (PEV), a clonally inherited pattern showing gene expression in some somatic cells but not in others. The mechanism responsible for this loss of gene expression is investigated here using fly lines carrying a P element containing the Drosophila melanogaster white and hsp26 genes. Following mobilization of the $P$ element, a screen for variegation of white expression recovered inserts at pericentric, telomeric, and fourth chromosome regions. Previously identified suppressors of PEV suppressed white variegation of pericentric and fourth chromosome inserts but not telomeric inserts on the second and third chromosomes. This implies a difference in the mechanism for gene repression at telomeres. Heat shock-induced $h s p 26$ expression was reduced from pericentric and fourth chromosome inserts but not from telomeric inserts. Chromatin structure analysis revealed that the variegating inserts showed a reduction in accessibility to restriction enzyme digestion in the $h s p 26$ regulatory region in isolated nuclei. Micrococcal nuclease digests showed that pericentric inserts were packaged in a more regular nucleosome array than that observed for euchromatic inserts. These data suggest that altered chromatin packaging plays a role in PEV.
\end{abstract}

[Key Words: Heterochromatin; chromatin; transgenes; centromeres; telomeres]

Received October 20, 1994; revised version accepted March 27, 1995.

The white gene resides in euchromatin at the distal end of the $\mathrm{X}$ chromosome (map position 1-1.5) and encodes a cell-autonomous protein required for pigmentation of the fly eye. When a chromosomal rearrangement occurs placing the white gene next to a breakpoint in heterochromatin, a mosaic pattern of expression is observed that is referred to as position effect variegation (PEV) /for reviews, see Lewis 1950; Baker 1968; Spofford 1976; Henikoff 1990). It has been suggested that heterochromatin formation, initiating within the normally heterochromatic region, spreads along the chromosome, encompassing the region of the white gene in some cells and rendering it transcriptionally inactive (Tartof et al. 1984). This inactive state would then be clonally inherited, giving rise to white patches within the eye. In other cells, heterochromatin formation might not spread sufficiently far to encompass the white gene, and white expression will be observed, giving rise to red patches in the eye. This hypothesis suggests that the lack of gene expression seen in PEV will be reflected in an altered chromatin structure. Other models proposed for the loss of gene expression associated with PEV are DNA elimination (Karpen and Spradling 1990; for review, see Spradling and Karpen 1990) and nuclear compartmentalizati-

${ }^{1}$ Corresponding author. zation (Wakimoto and Hearn 1990; for review, see Henikoff 1994).

The role of chromatin structure in gene regulation has been the focus of many recent studies (for reviews, see Elgin 1988; Grunstein 1990; Hayes and Wolffe 1992). First-order packaging of DNA into chromatin occurs when double-stranded DNA is wrapped around a histone octamer to form a nucleosome. The bulk of the DNA in the eukaryotic nucleus is packaged in an array of nucleosomes, forming the 10-nm fiber (van Holde 1989). Both in vitro and in vivo studies have demonstrated the importance of nucleosome positioning with respect to gene

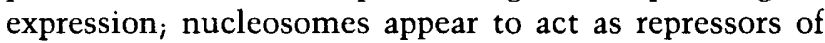
transcription when specifically positioned over the TATA box or other regulatory elements of a gene (for reviews, see Grunstein 1990; Thoma 1992; Workman and Buchman 1993; Lu et al. 1994). Much less is known about the packaging of chromatin beyond the $10-\mathrm{nm}$ fiber, as it is condensed into a $30-\mathrm{nm}$ fiber and further into the transcriptionally silent metaphase chromosome.

Heterochromatin has been defined as those regions of the chromosomes that remain condensed throughout the cell cycle (Heitz 1928). These regions are observed to be late replicating (Lima de Faria and Jaworska 1968) and are associated with a lack of gene expression, even for those sequences that might otherwise be active (e.g., the inactive mammalian X chromosome) (Lyon 1961; Rus- 
sell 1963). Regions of a genome that are packaged as heterochromatin are commonly found around centromeres and are generally made up of simple sequence repeats (Polizzi and Clarke 1991; Lohe et al. 1993). This chromatin is usually resistant to nuclease digestion and often shows exceptionally regular packaging /Cartwright et al. 1983; Funk et al. 1989; Doshi et al. 1991; Polizzi and Clarke 1991; Heus et al. 19931.

In Drosophila melanogaster, heterochromatin comprises $\sim 30 \%$ of the genome. In mitotic metaphase chromosomes, heterochromatin is located along the proxi$\mathrm{mal} 25 \%$ of the second and third chromosomes, the proximal $40 \%$ of the $\mathrm{X}$ chromosome, and interspersed along the length of the $\mathrm{Y}$ and fourth chromosomes (for review, see Hilliker et al. 1980). In salivary gland polytene chromosomes, euchromatic regions are replicated an average of 1000-fold and give a characteristic banded pattern, whereas heterochromatic regions are underrepresented and associated into a compact meshwork of fibers referred to as the chromocenter (Sorsa 1988). Drosophila heterochromatin has been categorized into two types: $\alpha$ and $\beta$-heterochromatin. $\alpha$-Heterochromatin, the major form, is located immediately adjacent to a centromere, is comprised primarily of simple sequence repeats (satellite DNA), and is thought to be relatively devoid of genes. $\beta$-Heterochromatin, the region connecting $\alpha$-heterochromatin to the euchromatic arms, is comprised primarily of middle repetitive sequences and is thought to have a gene density similar to that of euchromatin (Lakhotia and Jacob 1974; for review, see Miklos and Cotsell 1990).

To investigate the molecular mechanisms involved in the loss of gene expression attributable to PEV, we have used P-element mobilization to recover a variety of lines showing PEV and have determined the location, expression, and chromatin structure of the genes contained within the P-element insert. The marker gene used for detection of PEV is the D. melanogaster white gene; the test gene used for chromatin structure studies is the $D$. melanogaster heat shock protein 26 (hsp26) gene. The white gene is easily scored for PEV by visual inspection of the adult fly eye. There are several reasons for using $h s p 26$ as a test gene. $h s p 26$ is induced to high levels of expression in virtually every tissue of the fly upon heat shock treatment. This allows for measurements of expression and examination of chromatin structure using the entire organism, rather than dissected tissue. Induction of gene expression can be tested at any time during development. Furthermore, the chromatin structure of the hsp26 gene has been well characterized under nonheat shock and heat shock conditions /Cartwright and Elgin 1986; Thomas and Elgin 1988).

In this study, the hsp26 gene, tagged with a fragment of a barley cDNA, has been placed on a P-element plasmid with an hsp70-white gene as a reporter. Insertion into sites giving rise to PEV was monitored by screening for variegation of white expression. In all cases analyzed here, transgenes showing variegated white expression have inserted into sites within the pericentric heterochromatin, near telomeres, or along the fourth chromosome. Examination of the effects of genetic modifiers of
PEV on these transgenes suggests that the regions within the genome exhibiting PEV are neither functionally nor compositionally equivalent. In almost all cases, the expression and accessibility of the $h s p 26$ promoter region to restriction enzyme digestion in isolated nuclei was reduced compared with that of a transgene inserted at a nonvariegating euchromatic site. An altered chromatin structure was detected for the pericentric PEV inserts, providing evidence for a change in chromatin packaging as a molecular mechanism responsible for the loss of gene expression in this region.

\section{Results}

A screen for PEV of white expression results in recovery of inserts into pericentric, telomeric, and fourth chromosome regions

The hsp26 promoter region with a portion of the translated region was fused to a fragment of a cDNA from barley (which serves as a unique molecular tag), followed by the transcription termination sequence of the hsp 70 gene, creating the fusion gene $h s p 26-p t-T$ (Fig. 1). This fusion gene was cloned upstream of the hsp $70-$ white reporter gene in P-element vector A412 so that variegating inserts could be recovered by screening for PEV of hsp70-white in the flies eye. A similar reporter gene has been observed to exhibit PEV when inserted near the base of chromosome 3R (Steller and Pirrotta 1985). Under non-heat shock conditions white mutant flies transformed with this reporter gene in a euchromatic site have a uniform dark red eye phenotype (Fig. 2).

This P-element plasmid containing hsp26-pt-T and hsp70-white was injected into white mutant $D$. melanogaster embryos. Two lines with a single insertion on the X chromosome, designated 39C-X (insert at cytological region $2 \mathrm{D}$ ) and $118 \mathrm{E}-\mathrm{X}$ (insert at cytological region 19A-B), were used in a P-element mobilization scheme (see Materials and methods). A total of 7170 independent crosses were screened of which 2936 gave rise to redeyed male progeny, indicating that the $P$ element had mobilized to nonvariegating sites on other chromosomes. Thirty-five independently arising males were recovered that exhibited variegated $h s p 70$-white expression. The eye phenotype of seven representative lines homozygous for the P-element insert, verified by Southern blot analysis of genomic DNA (data not shown), are shown in Figure 2. In situ hybridization to polytene chromosomes showed that the hsp26-pt-T transgene had inserted at genomic locations that might be considered to be heterochromatic. Four lines had the $\mathrm{P}$ element inserted at pericentric locations, 9 lines had the P-element insert at telomeric locations, 18 lines had the P element inserted on the fourth chromosome, and 3 lines were lost. All but six lines are homozygous viable. The six lines that are homozygous lethal have transgenes inserted on the fourth chromosome. Examples of the in situ hybridizations to polytene chromosomes are shown in Figure 3. Lines 39C-3 and 39C-4 have an insert at the base of chromosome $\operatorname{arm} 2 \mathrm{~L}$; the sites of insertion for 


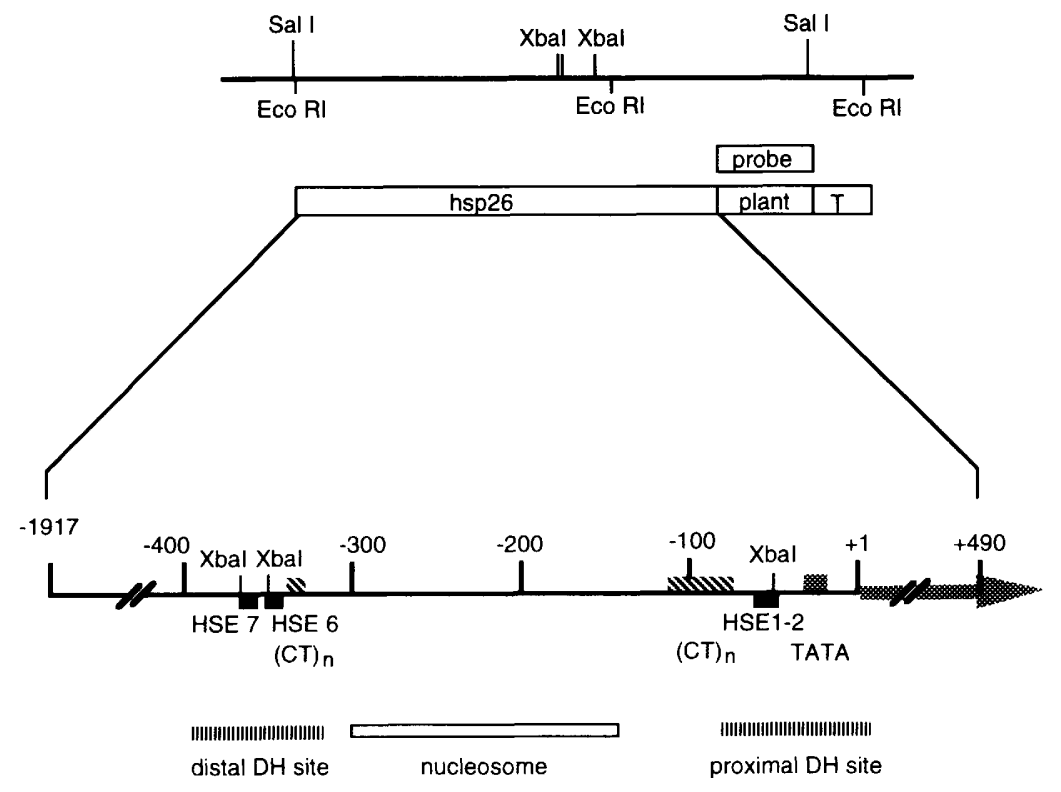

Figure 1. Map of the $h s p 26-p t-T$ transgene. The $h s p 26$ sequences from -1917 to +490 were fused to a 740 -bp fragment of a barley cDNA. The hsp70 transcription termination sequences were placed $3^{\prime}$ of the fusion gene and are designated T. Restriction sites used for molecular analyses are shown. An enlarged version of the map of the hsp26 sequences is shown below, with the $(\mathrm{CT})_{\mathrm{n}}$ regions (striped boxes), the TATA box (hatched box), and the HSEs (solid boxes) diagramed. Chromatin structural features are marked at the bottom. these two lines were different, as shown by restriction enzyme digestion of genomic DNA and subsequent Southern blotting (data not shown). Line $118 \mathrm{E}-12$ has an insert at the base of $3 \mathrm{R}$. The hybridization signal is very weak in this case because of the severe underrepresentation of the transgene in salivary gland DNA, as judged by Southern blot analysis (L.L. Wallrath, V. Gunter, and S.C.R. Elgin, unpubl.). Line $39 \mathrm{C}-5$ has an insert near the telomere of $2 \mathrm{~L}$. Lines $118 \mathrm{E}-10,39 \mathrm{C}-12$, and $118 \mathrm{E}-15$ have insertions near the base, in a medial position (cytological region $102 \mathrm{D}$ ) and near the telomere of the fourth chromosome, respectively. Interestingly, these regions of the chromosomes are known to be associated with heterochromatin protein 1 (HP1) in several strains of D. melanogaster, including the white mutant strain $y w^{67 c 23}$ used here (James et al. 1989; C. Craig and S.C.R. Elgin, unpubl.|. Several lines with extreme but uniform repression of white expression (possessing uniformly pale yellow eyes) were recovered in this screen and examined by in situ hybridization of their polytene chromosomes. The transgenes in these lines were inserted at sites within the euchromatic arms (banded regions) of chromosomes 2 and 3 . Thus, only the white variegated phenotype was indicative of insertions into regions thought to be heterochromatic.

Pericentric and fourth chromosome transgenes, but not telomeric transgenes, respond to known suppressors of PEV

Several mutant alleles of the suppressor of PEV Su(var) 205 have been shown to be mutations within the gene encoding HP1 (Eissenberg et al. 1990, 1992). We examined the consequences of introducing a mutant allele of the gene encoding HPl into the PEV lines. Females homozygous for a particular hsp 70-white variegating insert were crossed to control white males and to
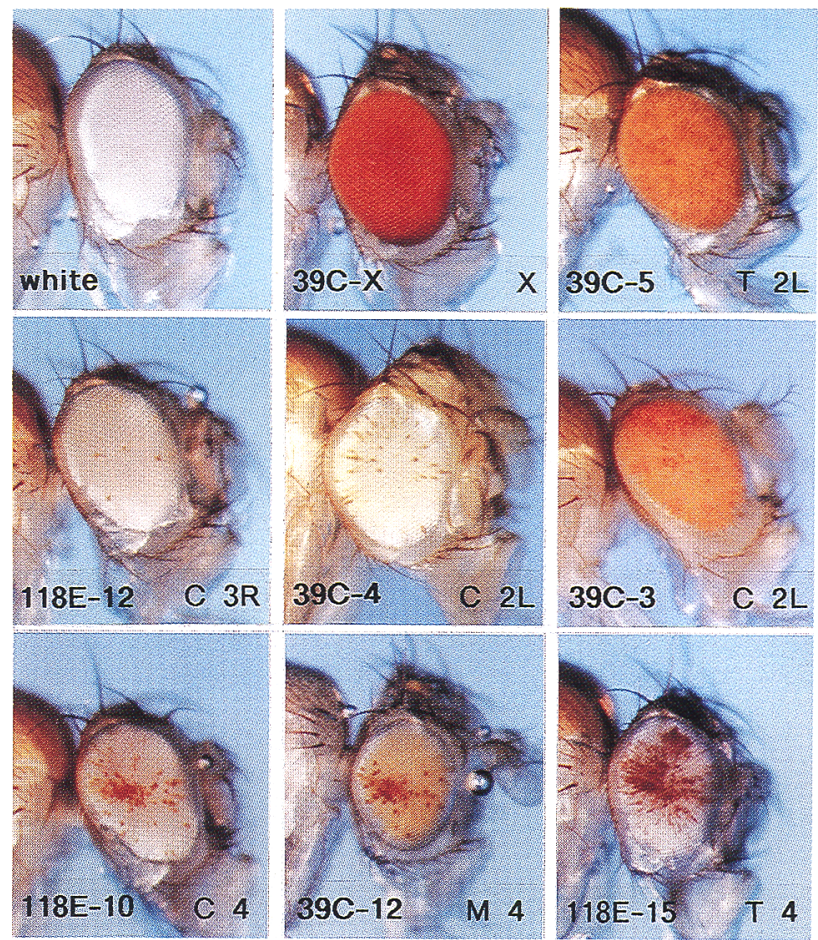

Figure 2. Eye phenotypes of starting stocks and lines obtained from the P-element mobilization scheme showing PEV of the hsp 70-white transgene. The white mutant host stock is shown in the upper left corner. Line designations are shown in the lower left corner and the chromosomal locations of the P-element inserts are shown in the lower right corner of each photograph. 39C-X has the transgene inserted into euchromatin of the $\mathrm{X}$ chromosome and was used as a starting stock for the P-element mobilization scheme. All flies are females and homozygous for the particular P-element insert. Abbreviations are as follows: $(\mathrm{X}) \mathrm{X}$ chromosome; (2L) left arm of the second chromosome; (3R) right arm of the third chromosome; (4) fourth chromosome; (C) pericentric; $(\mathrm{T})$ telomeric; $(\mathrm{M})$ medial. 


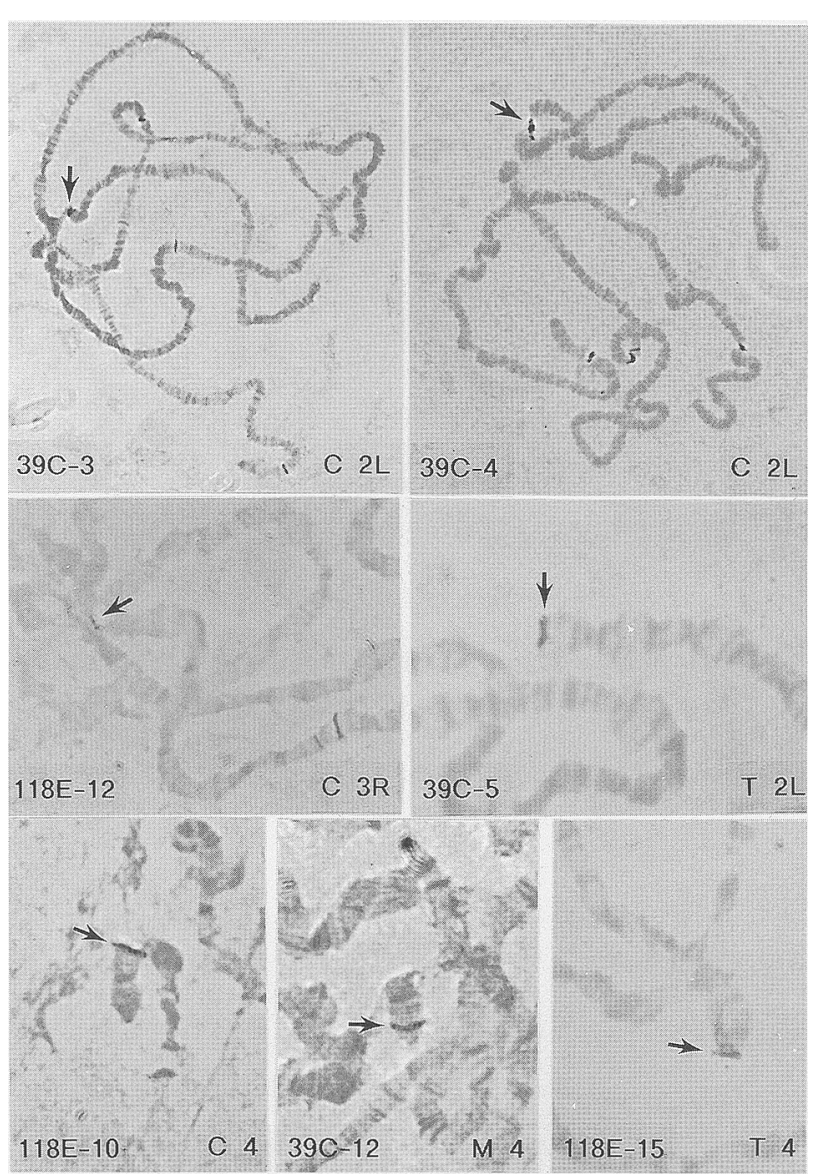

Figure 3. In situ hybridization to salivary gland polytene chromosomes from stocks showing PEV of the hsp 70 -white transgene. Labels are described in the legend to Fig. 2. Lines 39C-3 and $39 \mathrm{C}-4$ have the transgene inserted near the centromere of $2 \mathrm{~L}$, and line $118 \mathrm{E}-12$ has an insert near the centromere of $3 \mathrm{R}$. Line $39 \mathrm{C}-5$ has an insert at the telomere of $2 \mathrm{~L}$. Lines $18 \mathrm{E}-10$, $39 \mathrm{C}-12$, and $118 \mathrm{E}-15$ have inserts near the centromere, at a medial location (cytological position 102D), and near the telomere of the fourth chromosome, respectively. The probe used was the entire P-element plasmid that hybridized to the hsp26-pt-T transgene (arrow) as well as to the endogenous $h s p 26, h s p 70$, and white gene sequences.

males of a white stock possessing the $S u(v a r) 2-5^{02} \mathrm{mu}-$ tation, a missense mutation in the gene encoding HP1, which has a valine at amino acid position 26 changed to methionine (T. Hartnett and J.C. Eissenberg, pers. comm.). This amino acid substitution lies within the region of HP1 known as the chromo domain, a region of the protein with similarity to a region of the Polycomb protein as well as to other proteins thought to play a role in chromatin structure (for review, see Paro 1990; Lorentz et al. 1994; Tschiersch et al. 1994). This mutation, as well as three other mutant alleles of the gene encoding HP1, is homozygous lethal (Eissenberg et al. 1990, 1992). The eye phenotype of female progeny (having both wild-type and mutant HP1 protein) was compared with that of females hemizygous for the particular
P element (carrying the P element on one chromosome only) from the control backcross (see Materials and methods). Centromeric and fourth chromosome lines showed suppression of PEV in the presence of the Su(var)2-5 $5^{02}$ mutation (for examples, see Fig. 4). In contrast, six lines with insertions near the telomeres of $2 \mathrm{~L}, 2 \mathrm{R}$, or 3R showed no suppression (e.g., see Fig. 4, 39C-5). Note that line $39 \mathrm{C}-5$ shows strong PEV when the insert is in the hemizygous state but weak PEV when in the homozygous state (cf. Figs. 2 and 4). A similar phenomenon holds true for the additional telomeric insert lines. Most of the lines homozygous for an insert near the telomere of either $2 \mathrm{R}$ or $3 \mathrm{R}$ have an eye phenotype indistinguishable from that of lines carrying an insert within euchromatic regions (data not shown). The reason for this overly strong expression of the variegating transgenes at telomeres when homozygous is not clear; it does not occur in the lines with pericentric and fourth chromosome inserts, where little difference is observed between hemizygous and homozygous lines.

We also examined the effects of another suppressor of PEV, Su-var(2) $1^{01}$. Stocks possessing this mutation show an overabundance of acetylated histone $\mathrm{H} 4$ (Dorn et al. 1986). Females homozygous for a particular $h s p 70$-white variegating insert were crossed to males of a white mutant stock possessing the Su-var(2) $1^{O 1}$ mutation and to males of the white mutant stock as a control cross. The eye phenotypes of female progeny hemizygous for the $\mathrm{P}$ element and possessing the Su-var(2) $1^{01}$ mutation were compared to those of females hemizygous for the $P$ element from the control cross (see Materials and methods). Centromeric and fourth chromosome inserts showed suppression of variegation in response to the Su-var(2) $1^{01}$ mutation, but second and third chromosome telomeric inserts did not (for examples, see Fig. 4).

PEV resulting from genomic rearrangements has been shown to be suppressed by additional heterochromatin (Gowen and Gay 1933; for review, see Spofford 1976). To test whether additional heterochromatin suppresses the PEV of the inserts, males of a given transgenic line showing PEV of hsp 70-white were crossed to white mutant females with an attached-X chromosome $\left(X^{*}\right)$. The eye phenotype of $X / O$ male progeny and of $X X^{\wedge} / Y$ female progeny were compared with the eye phenotype of $X / Y$ males hemizygous for the particular $\mathrm{P}$ element. Four lines with inserts at pericentric locations and nine lines with inserts on the fourth chromosome showed suppression upon increasing the dosage of heterochromatin (for examples, see Fig. 5/. X/Y males had slightly greater eye pigmentation than $\mathrm{X} / \mathrm{O}$ males, and $\mathrm{X} \mathrm{X}^{\wedge} / \mathrm{Y}$ females showed dramatic increases in eye pigmentation compared with either $\mathrm{X} / \mathrm{O}$ or $\mathrm{X} / \mathrm{Y}$ males. Seven lines with inserts near the telomeres of $2 \mathrm{~L}, 3 \mathrm{~L}$, or $3 \mathrm{R}$ showed no change in eye phenotype (e.g., Fig. 5, see 39C-5).

hsp26 transgenes show a reduction in heat shockinduced expression that is derepressed by $\mathrm{Su}(\mathrm{var}) 2-5^{02}$

We next examined whether or not the hsp26 promoter would be responsive to heat shock when transposed to 


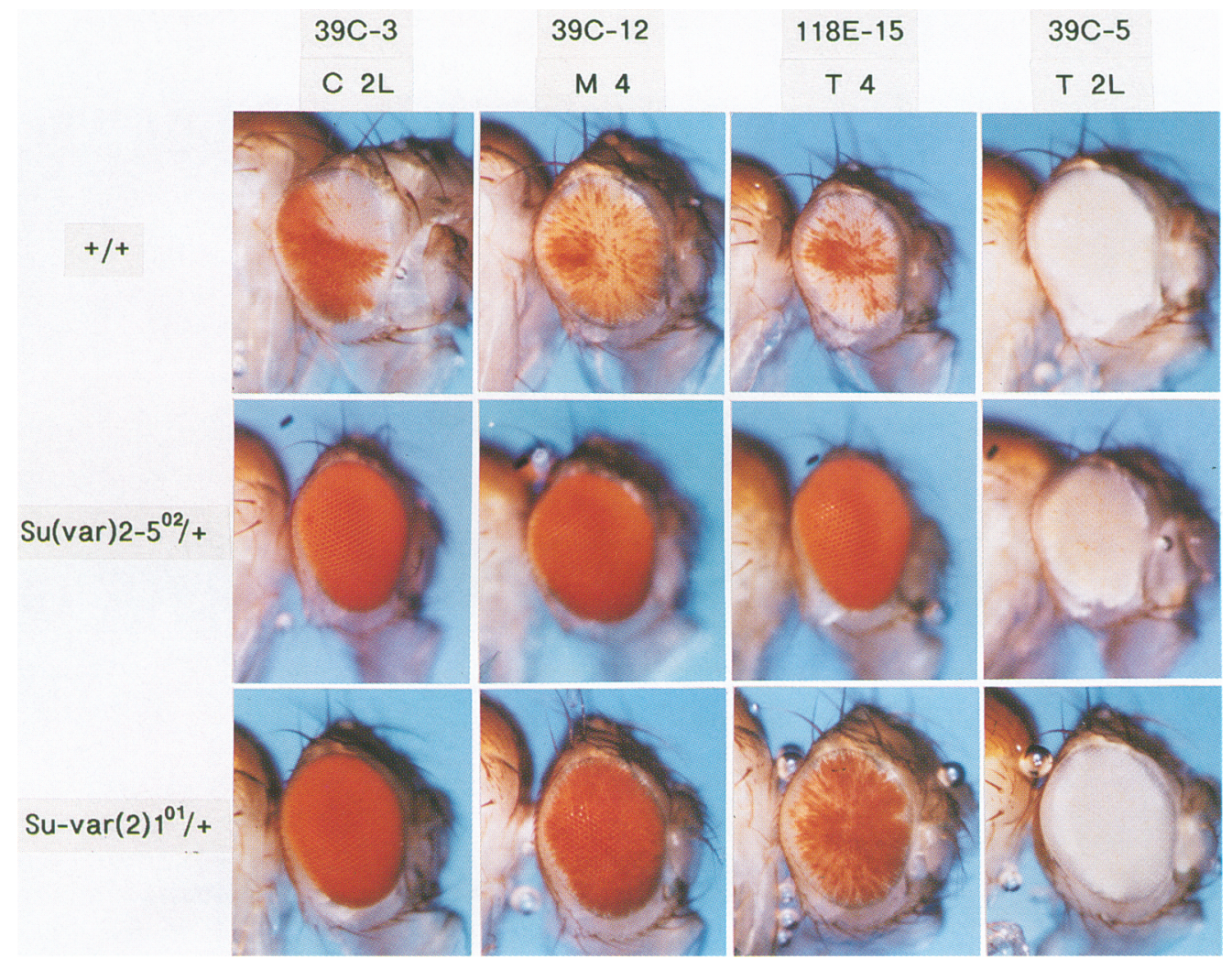

Figure 4. Effects of $S u(v a r) 2-5^{02}$ and $S u$-var(2) $1^{o 1}$ on PEV of $h s p 70$-white expression. Labels are described in the legend to Fig. 2. The eye phenotypes of females hemizygous for a particular transgene are shown with and without the $\operatorname{Su}(\mathrm{var}) 2-5^{02}$ and $\mathrm{Su}-\mathrm{var}(2) 1^{\mathrm{O} 1}$ mutations. Suppression of PEV of hsp70-white expression was noted in all cases shown except for line $39 \mathrm{C}-5$.

genomic locations that brought about PEV of hsp70white expression. Adult flies were heat-shocked at $37^{\circ} \mathrm{C}$ for $1 \mathrm{hr}$. Total RNA was extracted and examined by Northern blot analysis. Lines $39 \mathrm{C}-\mathrm{X}$ and $118 \mathrm{E}-\mathrm{X}$, with inserts into the euchromatic portion of the $\mathrm{X}$ chromosome, had identical values of hsp26-pt-T transgene expression after correcting for the amount of RNA in each lane using the rp49 signal intensity. The level of expression for these two lines was set at $100 \%$. As shown in Figure 6A, all the fly lines exhibiting PEV of $h s p 70$ white expression, with the exception of line 39C-5, showed a reduction in heat shock expression compared with lines $39 \mathrm{C}-\mathrm{X}$ and $118 \mathrm{E}-\mathrm{X}$. Lines $118 \mathrm{E}-12$ and $39 \mathrm{C}-4$ gave the lowest levels of heat shock-induced hsp26-pt-T transgene expression relative to those of the euchromatic insert lines, $4 \%$ and $13 \%$, respectively; these lines also show the smallest amount of eye pigmentation (Fig. 2). Line 39C-5, with the transgene inserted near the telomere of $2 \mathrm{~L}$, showed transcript levels comparable to those of the transgene inserted at euchromatic sites. Three additional lines homozygous for an insert near either the telomere of $2 \mathrm{R}$ or $3 \mathrm{R}$ also showed levels of induction of hsp26-pt-T message identical to that of the euchromatic controls (data not shown). Interestingly, the greatest amount of eye pigmentation is seen for the homozygous telomeric inserts (e.g., Fig. 2, see 39C-5). The pericentric and fourth chromosome insertion lines showed a reduction of $h s p 26-p t-T$ transgene expression relative to that of the euchromatic transgenes that correlated well with the amount of apparent $h s p 70$-white gene expression in the eye (Figs. 2 and 6A).

Repression of the basal level of expression of white from the $h s p 70$ promoter was suppressed in the presence of the $S u(v a r) 2-5^{02}$ allele in all cases examined except for the $2 \mathrm{~L}$ telomeric insert (Fig. 4). We tested whether or not the repression of heat shock-induced expression from the adjacent $h s p 26-p t-T$ promoter would be suppressed as well. Flies homozygous for a particular P-element insert were crossed to $w / Y$; Su(var)2-5 $-5^{02} / \mathrm{Cy}$ males. The $C y$ and non- $\mathrm{Cy}\left[\mathrm{Su}(\mathrm{var}) 2-5^{02}\right.$ possessing] adult progeny were collected separately, given a $1-\mathrm{hr}$ hour heat shock at $37^{\circ} \mathrm{C}$, and total RNA was isolated for Northern analysis (Fig. 6B). After normalization for RNA loading, the fold derepression of message from the $h s p 26-p t-T$ transgene in flies bearing the $S u(v a r) 2-5^{02}$ mutation was calculated based on the level of expression of the hsp26-pt-T transgene of the $C y$ siblings. As expected, the euchromatic insert line 39C-X showed no derepression of heat shockinduced expression of the $h s p 26-p t-T$ transgene; in fact, there was a small decrease in expression. Pericentric insertion line 39C-3 showed no change in the amount of induction; this appears to be attributable to the sensitiv- 
Figure 5. Effects of additional heterochromatin on PEV of hsp 70 -white transgene expression. Labels are described in the legend to Fig. 2. The eye phenotypes of $\mathrm{X} / \mathrm{O}$ males, $\mathrm{X} / \mathrm{Y}$ males, and $\mathrm{X} \mathrm{X}^{\wedge} / \mathrm{Y}$ females hemizygous for a particular transgene are shown. All of these lines showed suppression of PEV upon addition of heterochromatic material except line 39C-5.

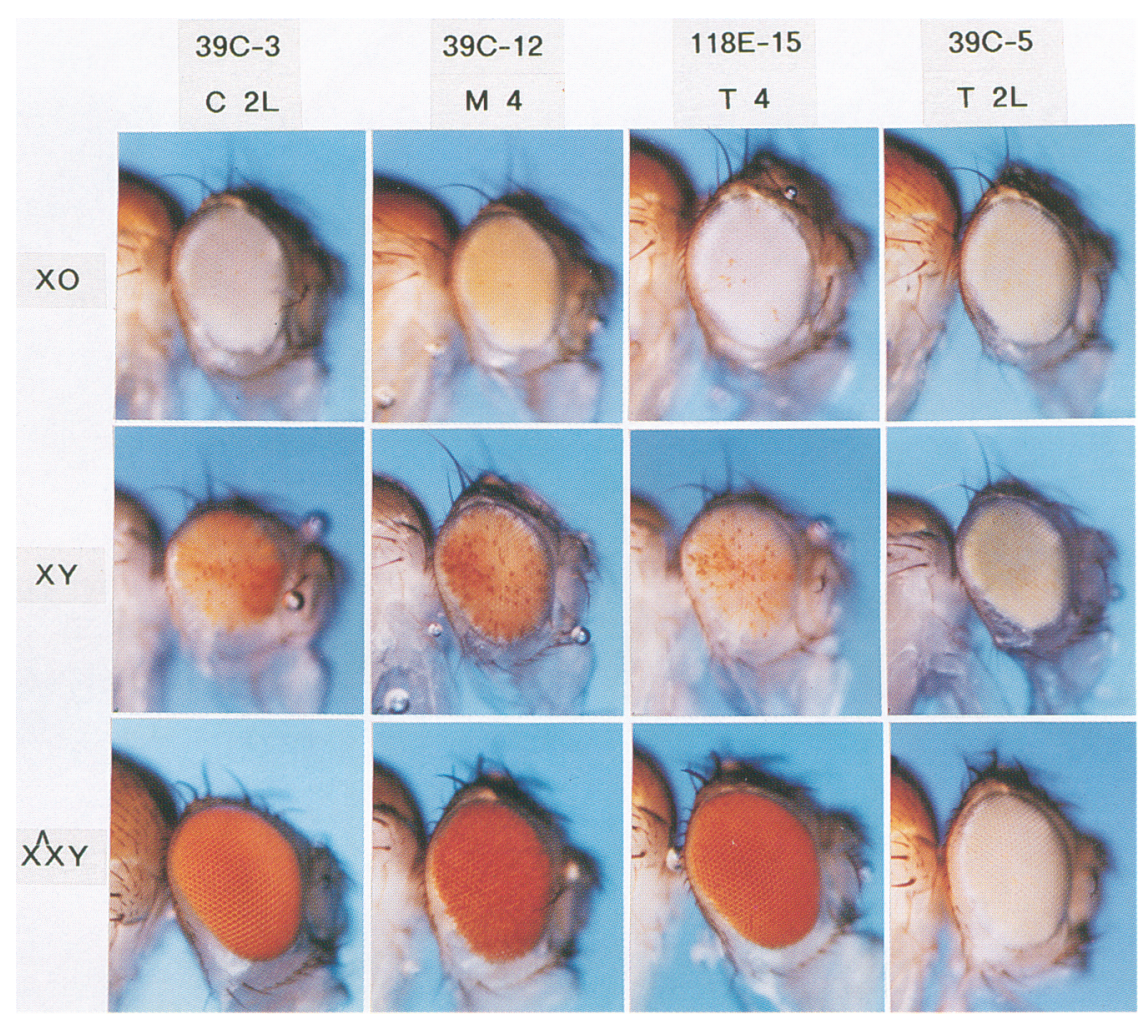

ity of this insert to a background suppressor on the $C y$ chromosome (see Materials and methods). All other lines with pericentric inserts, and fourth chromosome inserts showed derepression of $h s p 26-p t-T$ transgene expression (Fig. 6B). Line 118E-10, containing a pericentric insertion on the fourth chromosome, showed the greatest increase in expression, a 4.7-fold derepression. As was noted for white expression, telomeric insert line 39C-5 showed no increase in transgene expression in response to the Su(var) $2-5^{02}$ mutation. This lined showed a decrease in expression similar to that seen for the euchromatic insert.

\section{Variegating transgenes show a reduction in accessibility to restriction enzyme digestion}

We next examined the chromatin structure of the $h s p 26-p t-T$ transgenes to determine whether the reduced level of expression was associated with altered DNA packaging. The chromatin structure of hsp26 is

A

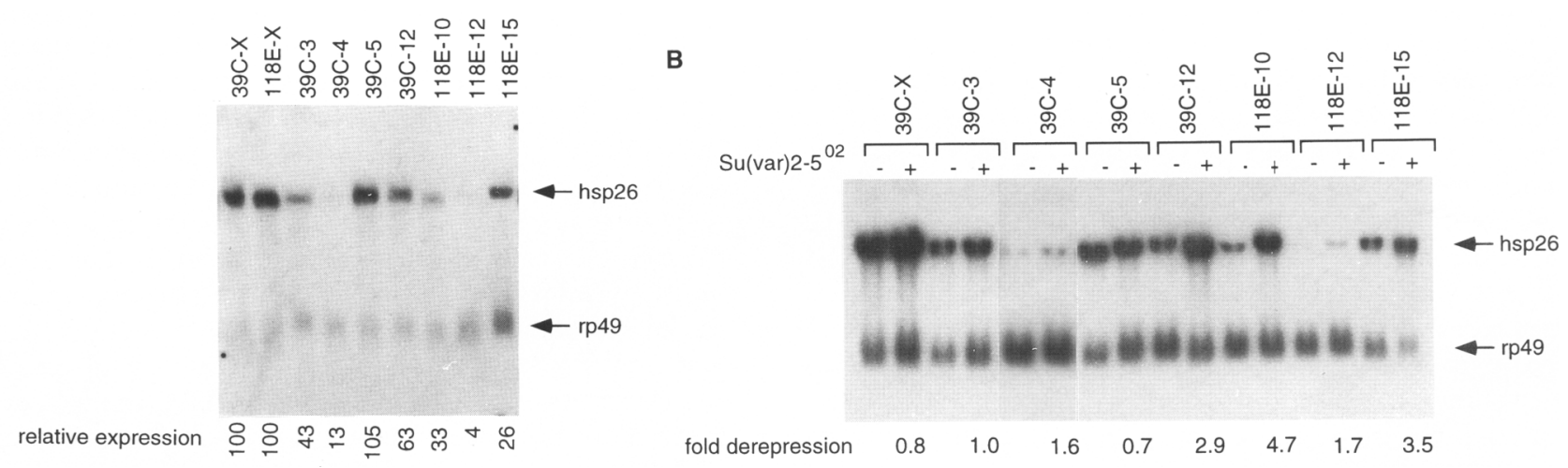

Figure 6. Northern analysis of heat shock-induced $h s p 26-p t-T$ transgene expression and derepression in response to $S u(v a r) 2-5^{02}$. $(A)$ Total RNA isolated from heat-shocked adults was separated by size on an agarose-formaldehyde gel and transferred to membrane. The membrane was hybridized simultaneously with the barley cDNA fragment (Fig. 1) and a plasmid containing a subclone of the rp49 gene (used as a control for normalizing total RNA loaded in each lane). The fly line used is indicated above each lane. The heat shock-induced expression for the samples from each PEV line relative to the X-linked starting stocks $(39 \mathrm{C}-\mathrm{X}$ and $118 \mathrm{E}-\mathrm{X}$, which had identical values) is indicated below each line. $(B \mid$ Total RNA was isolated and treated as described above. $1+$ and $-\mid$ The presence and absence, respectively, of the Su(var)2-5 $5^{\circ 2}$. The fold derepression (for calculation, see Materials and methods) of hsp26-pt-T expression in the presence of $\mathrm{Su}(\mathrm{var}) 2-5^{02}$ is shown. 
preset (for review, see Elgin 1988; Wallrath et al. 1994); no alterations in the nucleosome array of the promoter region are required for normal activation. There are two prominent DNase I hypersensitive sites (DH sites), nucleosome-free regions at the positions $5^{\prime}$ of the transcription start site that map to the location of the two required heat shock elements (HSEs, Fig. 1). Two stretches of alternating $C$ and $T$ residues, immediately adjacent to the HSEs, bind purified GAGA factor in vitro and are occupied by protein in vivo, presumably GAGA factor (Gilmour et al. 1989; Lu et al. 1993b). These elements have been shown to play a prominent role in generating the DH sites (Lu et al. 1992, 1993b). RNA polymerase II is associated with the promoter prior to heat shock induction, paused at position +25 (Rougvie and Lis 1990). Upon heat shock, heat shock factor (HSF) binds to the HSEs, triggering transcription. A nucleosome positioned specifically between the two DH sites (both before and after heat shock) may facilitate interaction between the two HSFs and possibly the GAGA factors, which are bound at either side of the nucleosome (Thomas and Elgin 1988).

The use of restriction enzymes is an effective means of quantitatively measuring the accessibility of a given site on a chromosome within the nucleus (Fascher et al. 1990; Jack and Eggert 1990; Archer et al. 1991; Jack et al. 1991; Lu et al. 1993a; Verdin et al. 1993; Schlossherr et al. 1994). Nuclei were isolated from non-heat-shocked third-instar larvae and incubated with an excess amount of XbaI, which cleaves within the HSEs (Fig. 1). The DNA was purified and digested to completion with SalI (Fig. 1). Using indirect end-labeling analysis with the barley cDNA fragment as a probe, the frequency of cleavage of the proximal $X b a I$ site (within HSE2) was quantified. The euchromatic hsp26-pt-T transgenes of lines 39C-X and $118 \mathrm{E}-\mathrm{X}$ gave cleavage values at the proximal $\mathrm{XbaI}$ site of $68 \%$ and $56 \%$, respectively. This amount of cleavage is similar to that seen for the endogenous $h s p 26$ gene or hsp26-lacZ transgenes when this region is DNase I hypersensitive (nucleosome-free) (Lu et al. 1992, $1993 \mathrm{a}, \mathrm{b})$. The value for line $39 \mathrm{C}-\mathrm{X}$ was set at $100 \%$. All of the variegating transgenes showed a reduction in accessibility of the proximal $\mathrm{XbaI}$ site in isolated nuclei; values ranged from $9 \%$ to $47 \%$ that of $39 \mathrm{C}$-X set at $100 \%$ (Fig. 7). Note that line $39 \mathrm{C}-5$ with the $2 \mathrm{~L}$ telomeric insert did show a reduction in accessibility of the $\mathrm{XbaI}$ site, although the level of heat shock-induced expression was identical to that of the euchromatic inserts. Perhaps HSF can compete against telomeric packaging proteins for binding to HSEs. The values shown for the accessibility of the proximal $\mathrm{XbaI}$ site for these transgenes in larval nuclei (which include polytene nuclei), correspond well with those obtained with nuclei isolated from adults (primarily comprised of diploid tissue; data not shown).

Pericentric transgenes are packaged in a more regular nucleosome array than euchromatic transgenes

The reduction in cleavage at the proximal $\mathrm{XbaI}$ site sug-

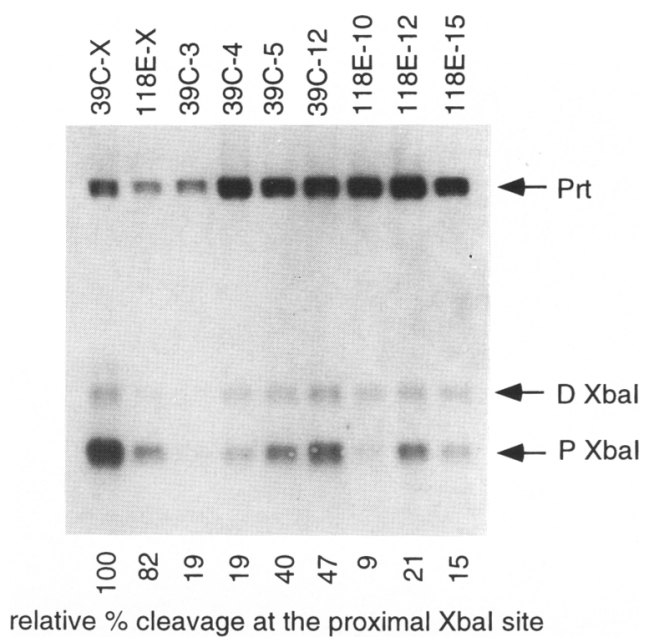

Figure 7. Accessibility of the proximal $\mathrm{XbaI}$ site in non-heatshocked larvae. Nuclei from non-heat-shocked third-instar larvae were isolated and incubated with an excess amount of $X b a I$. The DNA was purified and cleaved to completion with SalI, separated by size on a $1.2 \%$ agarose gel, transferred to membrane, and probed with the barley cDNA fragment (Fig. 1). (Prt) The parental SalI fragment not cleaved by XbaI. $\{\mathrm{P} X b a \mathrm{I}$ and $\mathrm{D}$ $X b a I)$ The products of cleavage at the proximal and distal $X b a I$ sites, respectively. Fly lines used as a source of nuclei are indicated above each lane. The percent cleavage of the proximal $\mathrm{XbaI}$ site relative to that of line $39 \mathrm{C}-\mathrm{X}$ is shown below each lane.

gests that the chromatin packaging of an insert showing PEV is altered compared with packaging in euchromatin. To examine the nucleosome array over the transgenes, a limited micrococcal nuclease digestion was performed. Micrococcal nuclease cleaves preferentially in linker DNA, having limited access to DNA associated with a histone core (Kornberg 1977). By definition, variegating lines have a mixture of cells expressing the transgene and cells not expressing the transgene (Fig. 2). To look for an altered chromatin structure associated with the lack of expression, we utilized those lines showing almost complete absence of expression of the transgenes (Fig. 2, $39 \mathrm{C}-4$ and $118 \mathrm{E}-12$ ). Nuclei were isolated from non-heatshocked larvae of variegating lines 39C-4 and $118 \mathrm{E}-12$ and from line $39 \mathrm{C}-\mathrm{X}$ as a control. Increasing amounts of micrococcal nuclease were added to aliquots of nuclei according to Lu et al. (1993a). The DNA was purified and separated by size on a $1.2 \%$ agarose gel. The ethidium bromide-stained gel is shown in Figure 8A (left). Note the similar extent of digestion for the three samples. The DNA was transferred to membrane and probed with the barley cDNA fragment (Fig. 1). The autoradiograph is also shown in Figure 8A (right). The overall pattern suggests that the variegating transgenes are digested somewhat more slowly that the control transgene. Lines $39 \mathrm{C}-4$ and $118 \mathrm{E}-12$ showed a very regular array of nucleosomes, implying constant spacing. In contrast, the euchromatic transgene $39 \mathrm{C}-\mathrm{X}$ had a less regular array of 

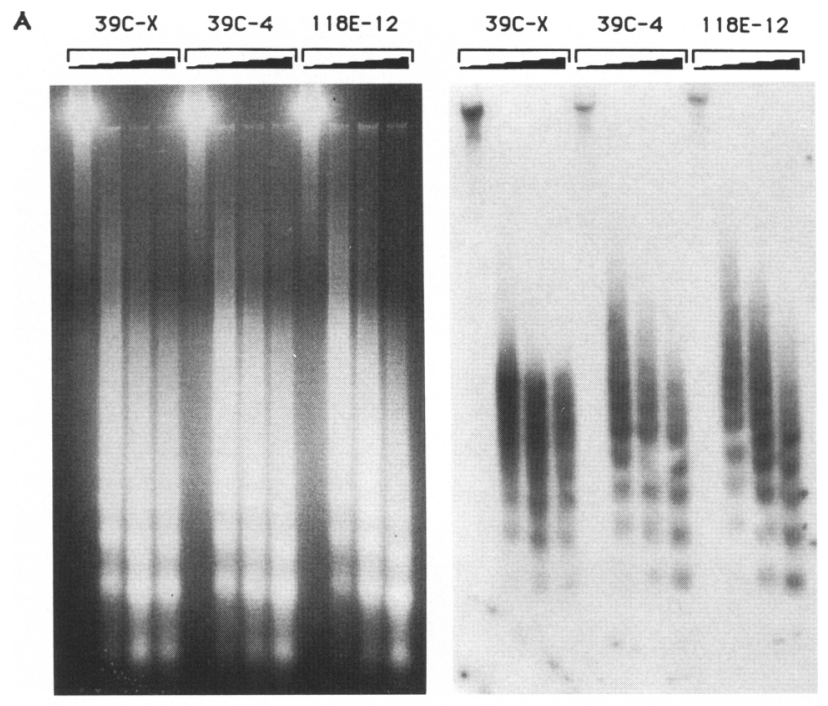

B
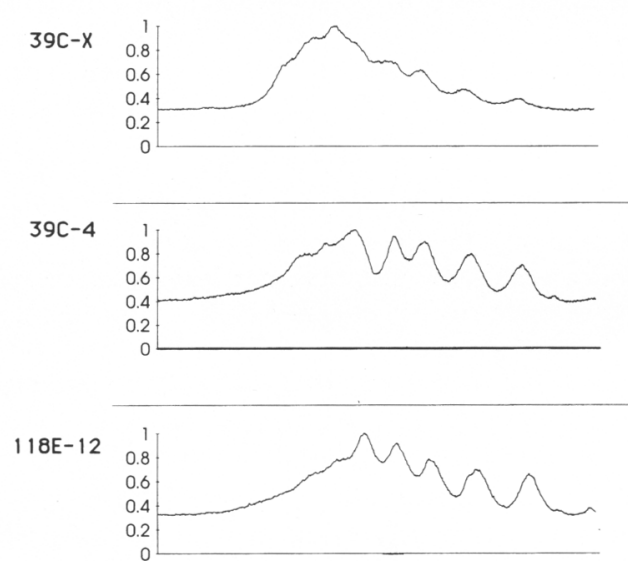

Figure 8. Micrococcal nuclease analysis of hsp26-pt-T transgenes. (A) Nuclei from third-instar larvae were isolated and incubated with increasing amounts of micrococcal nuclease. The DNA was purified and separated by size on a $1.2 \%$ agarose gel (ethidium bromide-stained gel, left), transferred to membrane, and probed with the barley cDNA fragment (Fig. 1) (autoradiograph of filter, right $).(B)$ Densitometric scans of the most digested lanes for each sample shown in $A$ (top to bottom of each lane is left to right along the $x$ axis). The $y$ axis designates arbitrary peak values with the highest peak in a given lane set at 1 .

nucleosomes, with more signal in the linker regions. This is best visualized by scans of the most extensively digested lanes for each of the samples (Fig. 8B). Scans of the micrococcal nuclease digestion products of the variegating transgenes showed sharp peaks and clear valleys indicative of an array of nucleosomes with consistent spacing, whereas the peaks and valleys of the nonvariegating insert were less discernible. Essentially an identical pattern to that of $39 \mathrm{C}-\mathrm{X}$ was obtained for euchromatic insert line $118 \mathrm{E}-12$ (data not shown). When the blot was stripped and reprobed with a fragment that hybridizes to the endogenous hsp 26 gene, and not the transgene, patterns were obtained for all three lines that were identical to the pattern seen for the euchromatic transgene (data not shown).

\section{Discussion}

The use of P-element transformation as a means of studying the structure and function of regions causing variegation

Heterochromatin has not been considered a likely target site for P-element integration. A few cases of P-element insertion into regions near centromeres, telomeres, or the fourth chromosome have been recovered using either the white gene or the xanthine dehydrogenase (rosy) gene as a reporter (Spradling and Rubin 1983; Hazelrigg et al. 1884; Steller and Pirrotta 1985; Clark and Chovnick 1986; Daniels et al. 1986; Kellum and Schedl 1991; Roseman et al. 1993; Tower et al. 1993). Transposition into heterochromatin may be rare because of a lack of target sites or altered DNA packaging that hinders accessibility. Physical proximity, transcriptional state, and similar time of replication of donor and acceptor sites may also play a role (Bownes 1990; Tower et al. 1993). However, there is a caveat; insertion into heterochromatin may go unnoticed if the particular reporter gene is silenced completely.

Karpen and Spradling (1992) recently screened for P-element transposition into Dp1187, a minichromosome with $-40 \%$ heterochromatin derived from the $\mathrm{X}$ chromosome using rosy ${ }^{+}$as a marker gene. Thirty-nine insertions into a subtelomeric region were recovered, but no insertions into pericentric regions were identified. Zhang and Spradling (1994) recovered an additional 32 heterochromatic insert lines using a rosy ${ }^{+}$P-element mobilization scheme that included the $\mathrm{Y}$ chromosome as a suppressor of $\mathrm{PEV}$; in some experiments an insert on the $\mathrm{Y}$ chromosome was used as a starting location for jumping. Several insertions into the $\mathrm{Y}$ chromosome and centric heterochromatin were recovered; many were homozygous lethal, suggesting that they identify genes that reside within centric heterochromatin.

We have taken a different approach and have screened for PEV of white in the absence of any mutations other than a null mutation for the endogenous white gene. This screen recovered insertions into the pericentric and telomeric regions of the second and third chromosomes, and into sites along the fourth chromosome. The majority of these inserts are probably in intergenic regions or nonessential genes, as most are homozygous viable. The inclusion of the hsp26 gene on the P element, a generally inducible gene for which the chromatin structure has been very well characterized (Cartwright and Elgin 1986; Thomas and Elgin 1988; Elgin et al. 1994l, allows for investigation of the mechanism of PEV. As noted by Cook and Karpen (1994), P-element "mutagenesis" is a useful means for performing a molecular genetic analysis on a part of the genome that has been difficult to study for quite some time. Different classes of insertion sites are being recovered by the different assays used in these screens, suggesting that the combined efforts in this area 
will be very informative in understanding heterochromatin structure.

Loss of gene expression at telomeres is based on a different mechanism than that operating at the centromeres and on the fourth chromosome

Drosophila telomeres are comprised of repetitive DNA sequences also found in centric heterochromatin and in the Y chromosome (Rubin 1977; Pardue and Hennig 1990; Valgeirsdottir et al. 1990; Levis et al. 1993). Telomeres are not observed as condensed structures in prophase (Gall et al. 1971), nor do they show C banding (Pimpinelli et al. 1976). Nevertheless, insertion of a euchromatic gene into a telomere insert brings about PEV of that gene (this study; Hazelrigg et al. 1984). This loss of expression of hsp 70 -white was not alleviated either by increases in centromeric heterochromatin or by $\mathrm{Su}\left(\right.$ var) $2-5^{02}$ or Su-var(2) $1^{01}$, two mutations that are predicted to alter chromatin structure. Note that the fourth chromosome telomeric line $118 \mathrm{E}-15$, as well as an additional fourth chromosome telomeric insert not shown here, did respond to the modifiers of PEV tested. It is surprising to discover that $S u(v a r) 2-5^{02}$ does not affect PEV at telomeres, as antibodies against HP1 do stain telomeres, albeit more weakly than the chromocenter and fourth chromosome staining (James et al. 1989). Perhaps more telling is the observation that $S u$-var(2) $1^{o 1} \mathrm{did}$ not suppress PEV at telomeres, because it affects the amount of acetylation of histone H4 (Dorn et al. 1986), a basic component of the nucleosome. With the exception of acetylation at lysine- 12 of histone $\mathrm{H} 4$, one observes underacetylation of the histone $\mathrm{H} 4$ amino-terminal tail in the heterochromatin of several organisms, including Drosophila and humans (Turner et al. 1990, 1992; Jeppesen et al. 1992; Jeppesen and Turner 1993|. It is reasonable to infer that hyperacetylation of histone $\mathrm{H} 4$ will be associated with a suppression of PEV, as high levels of histone $\mathrm{H} 4$ acetylation have been correlated with transcriptional activity of the active $\mathrm{X}$ chromosome in humans (Jeppesen and Turner 1993) and with the hyperactive $\mathrm{X}$ chromosome in male Drosophila (Bone et al. 1994).

The lack of suppression at telomeres reported here is similar to that obtained with a $3 \mathrm{R}$ telomeric white ${ }^{+}$insert that was found to be nonresponsive to several suppressors of brown Dominant (Talbert et al. 1994) and to modifiers of $w^{m 4}$ (R. Levis, cited within Talbert et al. 1994). Thus, it appears that the molecular properties that bring about PEV near telomeres may be different from those of variegating sites found near centromeres and along the fourth chromosome. Loss of expression at telomeres may be attributable to compartmentalization within the genome. Telomeres of Drosophila polytene chromosomes are found associated with the nuclear periphery, sometimes attached to the nuclear envelope (Hill and Whytock 1993).

Telomeres of both Saccharomyces cerevisiae and Schizosaccharomyces pombe also cause variegation of gene expression (Aparicio et al. 1991; Kyrion et al. 1993;
Nimmo et al. 1994). Telomere silencing in S. cerevisiae requires almost all of the proteins that are involved in silencing at the mating-type loci, $H M L$ and $H M R$ (for review, see Sandell and Zakian 1992). In particular, specific histone mutations that relieve silencing at the mating-type loci also relieve silencing at yeast telomeres (Thompson et al. 1994). The silencing observed at yeast telomeres exhibits the spreading effect observed for pericentric PEV in Drosophila (Renauld et al. 1993). For these reasons, heterochromatin formation has been inferred in the silencing at yeast telomeres (Greider 1992; Sandell and Zakian 1992; Wright and Shay 1992; Gilson et al. 1993). The situation in Drosophila appears to be different because the lack of gene expression at telomeres is not suppressed by the same factors that derepress transcription at the centromeres or along the fourth chromosome.

Loss of gene expression is correlated with a less accessible chromatin structure

In classical rearrangements giving rise to $\mathrm{PEV}$, genes up to 80 polytene chromosome bands $(\sim 2000 \mathrm{~kb})$ from the breakpoint have been shown to variegate (Demerec 1940). It therefore seemed likely that the hsp26-pt-T transgene, a few hundred base pairs from the variegating hsp 70-white transgene, should show transcriptional repression as well. Heat shock-induced chromosomal puffing (seen at the locations of heat shock genes upon transcription) has been shown to respond to PEV (Henikoff 1981). Furthermore, an hsp70-lacZ transgene shows cell-by-cell variegation of $\beta$-galactosidase expression in many tissues when present at sites that show PEV of a mini-white reporter gene (J. Eissenberg, pers. comm.). Pericentric and fourth chromosome insertion lines showed a reduction in heat shock-induced expression from the $h s p 26-p t-T$ transgene that correlated well with the apparent amount of eye pigmentation (expression of hsp 70-white) (cf. Figs. 2 and 6A). Because pigmentation (hsp70-white expression) varies greatly from cell to cell, the percent expression of $h s p 26-p t-T$ should be an average value of cells having very different levels of expression. Derepression of the $h s p 26-p t-T$ transgenes occurred in response to $\mathrm{Su}(\mathrm{var}) 2-5^{\circ 2}$ (Fig. 6B). Taken together, these data strongly suggest that the hsp26-pt-T transgenes are variegating.

Because previous work has shown that the wild-type hsp26 transgene has a highly defined chromatin structure, utilizing DH sites to provide access to the essential regulatory elements (Lu et al. 1992, 1993b), a possible mechanism for repression would be an alteration in the hsp26 preset chromatin structure. The accessibility of the $\mathrm{XbaI}$ sites within the HSEs can be measured quantitatively (see Results). All variegating hsp26-pt-T transgenes examined showed reduced accessibility of the proximal $X b a I$ site. It has been well documented that nucleosomes can block cleavage of a restriction site in vivo. Thus, it is tempting to speculate that the HSEs of the heterochromatic hsp26-pt-T transgenes are packaged in a nucleosome configuration different from that 
present in euchromatin. Alternately, the nucleosome packaging may be the same for euchromatic and heterochromatic inserts, but higher order packaging might account for the reduced accessibility to restriction enzyme digestion. However, there is a precedent for the genomic environment influencing nucleosomal distribution over a gene. Studies in $S$. pombe have revealed that genes that are normally packaged into regular arrays of nucleosomes are transcriptionally repressed and adopt an undefined packaging state when placed near the centromere; the undefined packaging state is a chromatin pattern typical of the centromeric regions themselves (Allshire et al. 1994).

The micrococcal nuclease digestion patterns (Fig. 8) reveal a difference in packaging of the pericentric inserts compared with the euchromatic inserts. The pericentric transgenes were packaged in a more regular nucleosome array. Interestingly, when the nucleosomal patterns over the Drosophila histone genes, 5S rRNA genes, and 1.688 gram $/ \mathrm{cm}^{3}$ complex satellite DNA sequence were compared, the satellite DNA showed the most prominent nucleosomal ladder, implying the most regular spacing (Cartwright et al. 1983). Several different repetitive DNA sequences (including the Drosophila 1.688 satellite) from many species have been shown to have nucleotide sequence patterns and bending properties similar to those of well-characterized nucleosome positioning sequences (Fitzgerald et al. 1994). Perhaps the heterochromatic insertion sites of lines $39 \mathrm{C}-4$ and $118 \mathrm{E}-12$ are within repetitive DNA elements that have highly defined nucleosome arrays, and this organization is imposed on the insert.

There have been a few earlier studies of the chromatin structure of a variegating gene near a heterochromatic rearrangement breakpoint. Hayashi et al. (1990) compared the sensitivity of DNase I digestion of the white gene in wild-type, variegating, and variegation-suppressed embryos. No major difference in the nuclease sensitivity was observed. The major limitation to this type of analysis is that it is not quantitative. Locke (1993) noted no difference in sensitivity to endogenous nucleases of a variegating white gene in DNA isolated from adult heads of stock possessing $S u(v a r)$ and $E n$ (var) mutations, provided there was an isogenic background. This type of assay is also not sensitive to quantitative differences. Finally, Schlossherr et al. (1994) elegantly performed quantitative chromatin structure analysis on small tissue samples by coupling restriction enzyme digestion with ligation-mediated PCR. They compared the accessibility of restriction sites within the white gene present on the $w^{m 4}$ chromosome in the background of the Su-var(2) $1^{01}$ mutation or of the En-var(2) $1^{01}$ mutation. No differences in restriction site access were noted in DNA from adult heads. However, one would not anticipate that the white gene would be inducible in the majority of these cells.

The hsp26 test gene has the advantage that it is normally packaged in an activatable chromatin structure in almost all cell types. Thus, it provides the greatest possible contrast to the inactive, heterochromatic state.
Prior characterization of the chromatin structure of this gene also aided in designing the assay. There is an excellent correlation between the accessibility of the proximal $X b a I$ site and the heat shock inducibility of the gene (Lu et al. 1992, 1993b). The work presented here shows that clear differences in chromatin structure are associated with pericentric PEV for this transgene. An additional reason why this study observed changes in chromatin structure associated with PEV while others did not may lie in the mechanism for achieving a variegating environment. Previous studies examined a white gene whose expression variegated because of a rearrangement in which a large block of euchromatin was brought into juxtaposition with a block of heterochromatin. In this study an $\sim 10-\mathrm{kb}$ fragment of euchromatic DNA has been inserted within or near heterochromatin, perhaps at a great distance from any large block of euchromatin.

\section{Possible molecular mechanisms responsible for PEV}

Three nonmutually exclusive mechanisms have been proposed to explain the lack of gene expression seen in PEV: (1) chromatin packaging (Tartof et al. 1984); (2) DNA elimination (Karpen and Spradling 1990; for review, see Spradling and Karpen 1990 and references therein); and (3) compartmentalization within the nucleus (Wakimoto and Hearn 1990; for review, see Henikoff 1994). Tartof and co-workers (1984) hypothesize that heterochromatin is packaged by multimeric protein complexes that begin formation at "initiation sites" and spread to "termination sites." Cytological evidence supports the hypothesis that alterations in DNA compaction and $\mathrm{HPl}$ association are correlated with changes in the transcriptional state of a variegating gene (Zhimulev et al. 1986; Belyaeva and Zhimulev 1991; Umbetova et al. 1991; Belyaeva et al. 1993).

Locke et al. (1988) proposed a mass-action model for the spreading of heterochromatin along a chromosome arm in which a limiting amount of one or more proteins of the multimeric complex dictates the extent of spreading. This general model is supported by several lines of evidence. In $D$. melanogaster there are estimated to be 120-150 loci which, when mutated, either suppress or enhance variegation (Wustmann et al. 1989). Genetic studies have shown that several autosomal genes which, when mutant or hemizygous, suppress PEV, can enhance PEV when present in three copies; likewise, several haplo-insufficient enhancers of PEV are triplo-suppressors of PEV. The wild-type alleles of several suppressors and enhancers of PEV have been characterized (for review, see Reuter and Spierer 1992; Baksa et al. 1993; Dorn et al. 1993; Tschiersch et al. 1994). All suppressors and enhancers of PEV mutations analyzed to date appear to be mutations in genes that encode chromosomal proteins or enzymes that modify these proteins. In support of the mass-action model, suppression of PEV also occurs upon addition of heterochromatic material. Heterochromatic sequences such as those that make up most of the Y chromosome appear to titrate heterochromatic pro- 
teins, resulting in suppression of PEV (Gowen and Gay 1933).

DNA elimination has also been proposed as a means of achieving PEV (Karpen and Spradling 1990; for review, see Spradling and Karpen 1990). This theory argues that if the gene is lost from the affected tissue, the repressed phenotype will result. Such DNA loss does occur in some cases (Spradling 1994), but there are several examples of PEV in which such loss has not occurred (Henikoff 1981; Rushlow et al. 1984; Hayashi et al. 1990; Umbetova et al. 1991). We find no significant change in DNA copy number of the $h s p 26-p t-T$ transgenes relative to the endogenous euchromatic hsp26 gene in DNA isolated from diploid tissue for the PEV lines shown here (L.L. Wallrath, L.E. Rosman, and S.C.R. Elgin, unpubl.). Alternatively, it has been suggested that gene repression associated with PEV may be attributable to compartmentalization within the nucleus (Wakimoto and Hearn 1990; for reviews, see Henikoff 1994; Karpen 1994). This theory argues for compartmentalization of transcriptional machinery within the nucleus, defined positions within the nucleus for different regions of the genome, and perhaps somatic pairing of homologous chromosomes to achieve PEV. Such a system could explain the difference in the response of the telomeric inserts /fourth chromosome vs. the second and third chromosome inserts) to various $\mathrm{Su}$ (var) mutations.

Analysis of the collection of variegating transgenes obtained here and those from similar studies should help to differentiate between these models. On the basis of the analysis presented here, we can conclude that chromatin packaging proteins and proteins involved in their modification are key players in the loss of gene expression seen for pericentric and fourth chromosome inserts. Results from the $\mathrm{XbaI}$ and micrococcal nuclease digestion analyses present evidence of altered DNA packaging as a mechanism for such PEV in Drosophila.

The hsp26 gene will serve as a good model system to examine the interplay of trans-acting regulatory factors and heterochromatin packaging proteins. Interestingly, mutations in the gene encoding GAGA factor were recently discovered to act as dominant enhancers of white variegation of stock $w^{\text {m4h }}$ (Farkas et al. 1994). However, when these mutations are present in the heterozygous state they do not show enhancement of PEV for the lines shown here (L.L. Wallrath and S.C.R. Elgin, unpubl.). Future work involving lines that overexpress GAGA factor and HSF will allow for in vivo competition studies.

\section{Materials and methods}

Drosophila stocks

All Drosophila stocks were raised on cornmeal sucrose-based media (Shaffer et al. 1994). All crosses were performed at $25^{\circ} \mathrm{C}$ unless stated otherwise. Similar age flies were used for all com. parisons.

\section{P-element transformation and mobilization}

P-element vectors containing the white gene as a reporter and an hsp26-lacZ fusion gene are unstable in Escherichia coli.
Therefore, the hsp26 gene was fused to a fragment of plant cDNA isolated from barley. The SacI fragment representing a portion of the coding sequences of the hsp26 gene of plasmid pMC1871.26 (Glaser et al. 1986) was deleted and a 773-bp SacI fragment of a cDNA encoding the barley SIP1 gene (G. Heck and D. Ho, unpubl.) was inserted (designated pt here). The recombinant plasmid was digested with Sall releasing the $h s p 26-p t$ fragment that was cloned into the SalI site of plasmid Car20T (called c70T in Xiao and Lis 1988). A clone containing an insert with the $\mathrm{T}$ transcription termination sequence of the $h s p 70$ gene juxtaposed to the barley cDNA fragment was identified by restriction enzyme analysis. The recombinant plasmid was partially digested with EcoRI, and the fragment containing the hsp26-pt-T fusion gene was cloned into the EcoRI site of the P-element vector A412 possessing an $h s p 70$-white gene as a reporter (kindly provided by V. Pirrotta, University of Geneva, Switzerland).

The resulting P-element construct and the helper P-element $\mathrm{p} \pi 25.7 \mathrm{wc}$ (Karess and Rubin 1984) were coinjected into white mutant $\left(y w^{67 c 23}\right)$ D. melanogaster embryos according to standard germ-line transformation procedures (Rubin and Spradling 1982). Transformants containing an intact single copy of the $P$ element, verified by genomic Southern blot analysis (data not shown|, inserted in euchromatin of the $\mathrm{X}$ chromosome were used in a P-element mobilization scheme. Females from two lines homozygous for the P-element insertion on the $\mathrm{X}$ chromosome (lines $39 \mathrm{C}-\mathrm{X}$ and $118 \mathrm{E}-\mathrm{X}$ ) were crossed to $w / Y, S b \Delta 2$ $3 /$ TM6 males with $\Delta 2-3$ serving as a genomic source of transposase (Robertson et al. 1988). The male progeny carrying the $S b$ $\Delta 2-3$ chromosome were crossed to females of the white mutant host stock. Male progeny showing PEV of hsp 70-white expression and lacking the $S b \Delta 2-3$ chromosome potentially had insertions into heterochromatin. PEV lines were made homozygous (verified by outcrossing to the white stock), and the site of insertion was determined by in situ hybridization to polytene chromosomes.

\section{In situ hybridization to polytene chromosomes}

Salivary glands were isolated from late third-instar larvae and prepared according to Ashburner (1989). Slides with dried chromosomes were pretreated for $30 \mathrm{~min}$ at $65^{\circ} \mathrm{C}$ in $2 \times \mathrm{SSC}, 10 \mathrm{~min}$ at $23^{\circ} \mathrm{C}$ in $2 \times \mathrm{SSC}, 2 \mathrm{~min}$ in freshly made $70 \mathrm{~mm} \mathrm{NaOH}$, twice for $5 \mathrm{~min}$ in $70 \%$ ethanol, and twice for $5 \mathrm{~min}$ in $95 \%$ ethanol. P-element plasmid ( $200 \mathrm{ng}$ ) was labeled using nick translation (Sambrook et al. 1989) in the presence of biotin-16-dUTP [Boehringer Mannheim Biochemicals (BM)]. One hundred microliters of hybridization solution $(2 \times \mathrm{SSC}, 50 \%$ formamide, $0.6 \mathrm{M} \mathrm{NaCl}$, $12.3 \mathrm{~mm}$ Tris- $\mathrm{HCl}$ at $\mathrm{pH} 7.5,5 \times$ Denhardt's solution, $1 \mathrm{~mm}$ EDTA , $0.1 \mu / \mathrm{ml}$ of dextran sulfate, and $0.3 \mathrm{mg} / \mathrm{ml}$ of sheared salmon sperm DNA) was added to the nick translation products; the mixture was boiled for $10 \mathrm{~min}$, placed on ice, and $15 \mu \mathrm{l}$ was added to each slide and covered with a coverslip. Hybridization took place at $45^{\circ} \mathrm{C}$ in a humid chamber overnight. Slides were washed three times for $20 \mathrm{~min}$ at $53^{\circ} \mathrm{C}$ in PBS, twice for 5 $\mathrm{min}$ at room temperature in PBS, once for $2 \mathrm{~min}$ at room temperature in PBS-TX $10.1 \%$ Triton X-100), and rinsed in PBS. The chromosomes were treated with a 1:250 dilution of the streptavidin-horseradish peroxidase complex (ENZO) for $30 \mathrm{~min}$ at $37^{\circ} \mathrm{C}$ in a humid chamber, rinsed in PBS three times for $5 \mathrm{~min}$ at room temperature, and once in PBS-TX for $2 \mathrm{~min}$ at room temperature and then placed in PBS. Hybridization was detected by incubation with $250 \mu \mathrm{l}$ of a $0.5 \mathrm{mg} / \mathrm{ml}$ solution of 3'-3'-diaminobenzidine in PBS with $0.01 \% \mathrm{H}_{2} \mathrm{O}_{2}$ for $15 \mathrm{~min}$ at room temperature. The slides were washed thoroughly with water and stained with $5 \%$ Giemsa (Sigma) in $10 \mathrm{~mm}$ phosphate 
buffer ( $\mathrm{pH}$ 6.8). This protocol was provided by the Ashburner laboratory for the 1992 EMBO Drosophila Molecular Cytogenetics Course on polytene chromosomes.

\section{Testing the effects of known modifiers of PEV}

To examine the effects of the Su(var)2-5 $5^{02}$ and Su-var(2) $1^{01} \mathrm{mu}$ tations on white expression, females homozygous for a particular insert were crossed to $w / Y$; Su(var)2-5 $5^{02} / C y$ or $w / Y$; Su-var(2) $1^{01} / C y$ males. The $C y$ balancer chromosomes were found to contain background suppressors of $\mathrm{PEV}$; therefore, the non- $C y$ progeny possessing the $S u(v a r)$ alleles were compared to flies hemizygous for the particular $\mathrm{P}$ element made by backcrossing a female homozygous for a particular $\mathrm{P}$ element to males of the white mutant host stock $y w^{67023}$. Only the least repressed pericentric inserts (such as line 39C-3) responded to the background suppressors on the $C y$ chromosome. For all other inserts, the eyes of the $C y$ progeny looked identical to those of the progeny from the backcross. To examine the effects of the $S u(v a r) 2-5^{02}$ mutation on hsp26-pt-T heat shock-induced expression, females homozygous for a particular insert were crossed to $w / Y ; S u(v a r) 2-5^{\circ 2} / C y$ males. The $C y$ and non-Cy [Su(var) $2-5^{02}$ possessing] siblings were separated and used for RNA isolation as described below.

To examine the effects of heterochromatin dosage, males homozygous for a particular P element were crossed to females of the stock C(1)RM, yw f/YS.X, In(1)EN, vptg oc sn $n^{5} w y, Y L s c^{8}$ $y^{+}$(a Y chromosome-free stock). X/O and $X X^{\wedge} / Y$ progeny were compared with $\mathrm{X} / \mathrm{Y}$ flies hemizygous for the particular P-element insert made by backcrossing to the white mutant stock.

\section{Northern analysis}

Twenty-five adult flies of the desired genotype were heatshocked at $37^{\circ} \mathrm{C}$ for $1 \mathrm{hr}$, and total RNA was isolated (Wallrath et al. 1990). The RNA was fractionated on a $1.2 \%$ (wt/vol) agarose gel with formaldehyde and transferred to a nylon membrane (Sambrook et al. 1989). The membrane was probed simultaneously with a plasmid containing the $r p 49$ gene (Wong et al. 1981) and the barley DNA fragment (Fig. 1). For Figure 6A, the probes were labeled with digoxigenin-dUTP (BM) using random primers (Feinberg and Vogelstein 1984). For Figure 6B, the probes were labeled with $\left|\alpha^{-{ }^{32}} \mathrm{P}\right| \mathrm{dATP}$ and $\left|\alpha^{-{ }^{32}} \mathrm{P}\right| \mathrm{dCTP}$ using random primers. Hybridization and wash conditions were according to Lu et al. (1992). Hybridization products were detected using the chemiluminescent alkaline phosphatase detection system (BM) for the nonradioactive probes. The intensity of the bands on the lumigraph (Fig. 6A) and autoradiograph (Fig. 6B) was quantitated using a scanning densitometer (Molecular Dynamics). Differences in the amount of RNA loaded in each lane were corrected using the signal intensity of $r p 49$. For Figure 6A the levels of expression of the $h s p 26-p t-T$ transgenes inserted into euchromatin (lines 39C-X and $118 \mathrm{E}-\mathrm{X}$ ) were identical and set at $100 \%$ expression. The values for the levels of $h s p 26-p t-T$ transgenes inserted into heterochromatic sites are given relative to that of the euchromatic insert lines. For Figure 6B, the fold derepression was calculated by dividing the arbitrary number for the pixel volume from the scan for the $h s p 26-p t-T$ signal obtained without the Su(var)2-5 $5^{12}$ by the value obtained with the $S u(v a r) 2-5^{02}$ present, after normalizing for RNA loading. Independent trials using the same stocks showed an average of $\pm 7 \%$ variation in expression levels.

\section{Chromatin structure analysis}

Nuclei were isolated from non-heat-shocked larvae raised at $22^{\circ} \mathrm{C}$ for each of the transformed lines according to previously published procedures (Lu et al. 1993a). The nuclei were treated with an excess amount of $X b a I$ and the DNA isolated (Lu et al. 1993a). Purified genomic DNA was then cleaved to completion with Sall (Fig. 1) and size fractionated on a $1.2 \%$ agarose gel. The DNA was transferred to nylon membrane and hybridized with the barley cDNA fragment labeled using random primers (Feinberg and Vogelstein 1984) and digoxigenin-dUTP (BM). Hybridization conditions and washes were according to Lu et al. (1992). Hybridization products were detected using the chemiluminescent alkaline phosphatase detection system (BM). The lumigraph of the Southern blot was scanned with a densitometer (Molecular Dynamics). Scans of lumigraphs from different exposure times gave similar values. The percent cleavage at the proximal site was calculated by measuring the intensity of the band produced from cleavage at the proximal site compared wih the total intensity of the bands in a given lane. Line $39 \mathrm{C}-\mathrm{X}$ showed the greatest cleavage at the proximal $\mathrm{XbaI}$ site and was set at $100 \%$. Values for the cleavage at the proximal site in all other lines are given relative to line $39 \mathrm{C}-\mathrm{X}$. Variation for the measurements of $X b a I$ accessibility is approximately $\pm 5 \%$ (this study; Lu et al. 1993b).

For micrococal nuclease analysis, nuclei were isolated from third instar raised at $22^{\circ} \mathrm{C}$ and digested with increasing amounts of micrococcal nuclease according to Lu et al. (1993a). In this case, 250- $\mu$ l aliquots of nuclei were incubated with either 0,2 , 4 , or $6 \mu \mathrm{l}$ of a micrococcal nuclease stock solution 10.008 $\mathrm{U} / \mu \mathrm{l}$ ) for $2 \mathrm{~min}$ at room temperature. The DNA was purified and separated by size on a $1.2 \%$ agarose gel by electrophoresis at $4^{\circ} \mathrm{C}$. The ethidium bromide-stained gel is shown in Figure 8 (left). The DNA was transferred to nylon membrane and probed with the barley cDNA fragment (Fig. 1) labeled using random primers (Feinberg and Vogelstein 1994) in the presence of $\left|\alpha{ }^{-32} \mathrm{P}\right| \mathrm{dATP}$ and $\left[\alpha{ }^{-32} \mathrm{P} \mid \mathrm{dCTP}\right.$. The autoradiograph was scanned using a scanning densitometer (Molecular Dynamics).

\section{Acknowledgments}

We thank V. Pirrotta for the P-element plasmid A412, J. Eissenberg for the Su(var) stocks, F. Karch for the Trl stocks, L. Rosman for technical assistance, and members of the Elgin laboratory for comments and suggestions. We thank J. Eissenberg, $T$. Friedman, L. Robbins, and J. Spofford for helpful comments regarding previous versions of this manuscript. We appreciate the comments of B. Wakimoto and two anonymous reviewers. This work was supported by National Institutes of Health (NIH) grant HD23844 to S.C.R.E. and NIH National Service Award GM14516 to L.L.W.

The publication costs of this article were defrayed in part by payment of page charges. This article must therefore be hereby marked "advertisement" in accordance with 18 USC section 1734 solely to indicate this fact.

\section{References}

Allshire, R.C., J.-P. Javerzat, N.J. Redhead, and G. Cranston. 1994. Position effect variegation at fission yeast centromeres. Cell 76: 157-169.

Aparicio, O.M., B.L. Billington, and D.E. Gottschling. 1991. Modifiers of position effect are shared between telomeric and silent mating-type loci in S. cerevisiae. Cell 66: 12791287.

Archer, T.K., M.G. Cordingly, R.G. Wolford, and G.L. Hager. 1991. Transcription factor access is mediated by accurately positioned nucleosomes on the mouse mammary tumor virus promoter. Mol. Cell. Biol. 11: 688-698. 
Ashburner, M. 1989. Preparation of polytene chromosomes. In Drosophila: A laboratory manual. pp. 37-38, Cold Spring Harbor Laboratory Press, Cold Spring Harbor, New York.

Baker, W.K. 1968. Position-effect variegation. Adv. Genet. 14: $133-169$.

Baksa, K., H. Morawietz, V. Dombrádi, M. Axton, H. Taubert, G. Szabó, I. Török, H. Gyurkovics, B. Szöör, D. Glover, G. Reuter, and I. Gausz. 1993. Mutations in the protein phosphatase 1 gene at $87 \mathrm{~B}$ can differentially affect suppression of position-effect variegation and mitosis in Drosophila melanogaster. Genetics 135: 117-125.

Belyaeva, E.S. and I.F. Zhimulev. 1991. Cytogenetic and molecular aspects of position effect variegation in Drosophila. III. Continuous and discontinuous compaction of chromosomal material as a result of position effect variegation. Chromosoma 100: 453-466.

Belyaeva, E.S., O.V. Demakova, G.H. Umbetova, and I.F. Zhimulev. 1993. Cytogenetic and molecular aspects of position-effect variegation in Drosophila melanogaster. V. Heterochromatin-associated protein HPl appears in euchromatic chromosomal regions that are inactivated as a result of position-effect variegation. Chromosoma 102: 583-590.

Bone, J.R., J.S. Lavender, R. Richman, M.J. Palmer, B.M. Turner, and M.I. Kuroda. 1994. Acetylated histone $\mathrm{H} 4$ on the male X chromosome is associated with dosage compensation in Drosophila. Genes \& Dev. 8: 96-104.

Bownes, M. 1990. Preferential insertion of $\mathrm{P}$ elements into genes expressed in the germ-line of Drosophila melanogaster. Mol. \& Gen. Genet. 222: 457-460.

Cartwright, I.L. and S.C.R. Elgin. 1986. Nucleosomal instability and induction of new upstream protein-DNA associations accompany activation of four small heat shock protein genes in Drosophila melanogaster. Mol. Cell. Biol. 6: 779-791.

Cartwright, I.L., R.P. Hertzberg, P.B. Dervan, and S.C.R. Elgin. 1983. Cleavage of chromatin with methidiumpropylEDTA - iron(II). Proc. Natl. Acad. Sci. 80: 3213-3217.

Clark, S.H. and A. Chovnick. 1986. Studies of normal and position-affected expression of rosy region genes in Drosophila melanogaster. Genetics 114: 819-840.

Cook, K.R. and G.H. Karpen. 1994. A rosy future for heterochromatin. Proc. Natl. Acad. Sci. 91: 5219-5221.

Daniels, S.B., M. McCarron, C. Love, S.H. Clark, and A. Chovnick. 1986. The underlying bases of gene expression: Differences in stable transformants of the rosy locus in Drosophila melanogaster. Genetics 113: 265-285.

Demerec, M. 1940. Genetic behavior of euchromatic segments inserted into heterochromatin. Genetics 25: 618-627.

Dorn, R., S. Heymann, R. Lindigkeit, and G. Reuter. 1986. Suppressor mutation of position-effect variegation in Drosophila melanogaster affecting chromatin properties. Chromosoma 93: 398-403.

Dorn, R., V. Krauss, G. Reuter, and H. Saumweber. 1993. The enhancer of position-effect variegation of Drosophila, $E$ (var)3-93D, encodes for a chromatin protein containing a conserved domain common to several transcriptional regulators. Proc. Nat. Acad. Sci. 90: 11376-11380.

Doshi, P., S. Kaushal, C. Benyajati, and C.-I. Wu. 1991. Molecular analysis of the responder satellite DNA in Drosophila melanogaster: DNA bending, nucleosome structure, and Rsp-binding proteins. Mol. Biol. Evol. 8: 721-741.

Eissenberg, J.C., T.C. James, D.M. Foster-Hartnett, T. Hartnett, V. Ngan, and S.C.R. Elgin. 1990. Mutation in a heterochromatin-specific chromosomal protein is associated with suppression of position-effect variegation in Drosophila melanogaster. Proc. Natl. Acad. Sci. 87: 9923-9927.

Eissenberg, J.C., G.D. Morris, G. Reuter, and T. Hartnett. 1992.
The heterochromatin-associated protein HP-1 is an essential protein in Drosophila with dosage-dependent effects on position-effect variegation. Genetics 131: 345-352.

Elgin, S.C.R. 1988. The formation and function of DNase I hypersensitive sites in the process of gene activation. J. Biol. Chem. 263: 19259-19262.

Elgin, S.C.R, H. Granok, Q. Lu, and L.L. Wallrath. 1994. Role of chromatin structure in regulating gene expression: the hsp26 gene of Drosophila melanogaster. Cold Spring Harbor Symp. Quant. Biol. 59: 83-96.

Farkas, G., J. Gausz, M. Galloni, G. Reuter, H. Gyurkovics and F. Karch. 1994. The Trithorax-like gene encodes the Drosophila GAGA factor. Nature 371: 806-808.

Fascher, K.D., J. Schmitz, and W. Hörz. 1990. Role of transacting proteins in the generation of active chromatin at the PHO5 promoter in S. cerevisiae. EMBO I. 9: 2523-2528.

Feinberg, A.P. and B. Vogelstein. 1984. A technique for radiolabeling DNA restriction endonuclease fragments to high specific activity. Anal. Biochem. 137: 266-267.

Fitzgerald, D.J., G.L. Dryden, E.C. Bronson, J.S. Williams, and J.N. Anderson. 1994. Conserved patterns of bending in satellite and nucleosome positioning DNA. I. Biol. Chem. 269: 21303-21314.

Funk, M., J.H. Hegemann, and P. Philippsen. 1989. Chromatin digestion with restriction endonucleases reveals $150-160 \mathrm{bp}$ of protected DNA in the centromere of chromosome XIV in Saccharomyces cerevisiae. Mol. \& Gen. Genet. 219: 153160.

Gall, J.G., E.H. Cohen, and M.L. Polan. 1971. Repetitive DNA sequences in Drosophila. Chromosoma 33: 319-344.

Gilmour, D.S., G.H. Thomas, and S.C.R. Elgin. 1989. Drosophila nuclear proteins bind to regions of alternating $\mathrm{C}$ and $\mathrm{T}$ residues in gene promoters. Science 245: 1487-1490.

Gilson, E., T. Laroche, and S.M. Gasser. 1993. Telomeres and the functional architecture of the nucleus. Trends Cell Biol. 3: $128-134$.

Glaser, R.L., M.F. Wolfner, and J.T. Lis. 1986. Spatial and temporal expression pattern of $h s p 26$ expression during normal development. $E M B O$ I. 5: 747-754.

Gowen, J.W. and E.H. Gay. 1933. Eversporting as a function of the Y chromosome in Drosophila melanogaster. Proc. Natl. Acad. Sci. 19: 122-126.

Greider, C.W. 1992. Telomere chromatin and gene expression. Curr. Biol. 2: 62-64.

Grunstein, M. 1990. Histone function in transcription. Annu. Rev. Cell Biol. 6: 643-678.

Hayashi, S., A. Ruddell, D. Sinclair, and T. Grigliatti. 1990. Chromosomal structure is altered by mutations that suppress or enhance position effect variegation. Chromosoma 99: 391-400.

Hayes, J.J. and A.P. Wolffe. 1992. The interaction of transcription factors with nucleosomal DNA. BioEssays 14: 597-603.

Hazelrigg, T., R. Levis, and G.M. Rubin. 1984. Transformation of white locus DNA in Drosophila: Dosage compensation, zeste interaction, and position effects. Cell 36: 469-481.

Heitz, E. 1928. Das heterochromatin der moose. Jahrb. Wiss. Bot. 69: 726-818.

Henikoff, S. 1981. Position-effect variegation and chromosome structure of a heat shock puff in Drosophila. Chromosoma 83: 381-393.

. 1990. Position-effect variegation after 60 years. Trends Genet. 6: 422-426.

- 1994. A reconsideration of the mechanisms of position effect. Genetics 138: 1-5.

Heus, J.J., K.S. Bloom, B.J.M. Zonneveld, H.Y. de Steensma, and J.A. Van den Berg. 1993. Chromatin structures of Kluyvero- 
myces lactis centromeres in $K$. lactis and Saccharomyces cerevisiae. Chromosoma 102: 660-667.

Hilliker, A.J., R. Appels, and A. Schalet. 1980. The genetic analysis of D. melanogaster heterochromatin. Cell 21: 607-619.

Hill, R.J. and S. Whytock. 1993. Cytological structure of the native polytene salivary gland nucleus of Drosophila melanogaster: A microsurgical analysis. Chromosoma 102: 446456.

Jack, R.S. and H. Eggert, H. 1990. Restriction enzymes have limited access to DNA sequences in Drosophila chromosomes. Eur. I. Biochem. 202: 441-446.

Jack, R.S., P. Moritz, and S. Cremer. 1991. Restriction enzymes permit quantitative determination of defined chromatin structures within the chromosome. EMBO I. 9: 2603-2609.

James, T.C., J.C. Eissenberg, C. Craig, V. Dietrich, A. Hobson, and S.C.R. Elgin. 1989. Distribution patterns of HPl, a heterochromatin-associated nonhistone chromosomal protein of Drosophila. Eur. J. Cell Biol. 50: 179-180.

Jeppesen, P. and B.M. Turner. 1993. The inactive X chromosome in female mammals is distinguished by a lack of histone $\mathrm{H} 4$ acetylation, a cytological marker for gene expression. Cell 74: 281-289.

Jeppesen, P., A. Mitchell, B. Turner, and P. Perry. 1992. Antibodies to defined histone epitopes reveal variations in chromatin conformation and underacetylation of centric heterochromatin in human metaphase chromosomes. Chromosoma 101: 322-332.

Karess, R.E. and G.M. Rubin. 1984. Analysis of P transposable element functions in Drosophila. Cell 38: 135-146.

Karpen, G.H. 1994. Position-effect variegation and the new biology of heterochromatin. Curr. Opin. Genet. Dev. 4: 281291.

Karpen, G.H. and A.C. Spradling. 1990. Reduced DNA polytenization of a minichromosome region undergoing position-effect variegation in Drosophila. Cell 63: 97-107.

. 1992. Analysis of subtelomeric heterochromatin in the Drosophila minichromosome Dp1187 by single P element insertional mutagenesis. Genetics 132: 737-753.

Kellum, R. and P. Schedl. 1991. A position-effect assay for boundaries of higher order chromosomal domains. Cell 64: 941-950.

Kornberg, R. 1977. Structure of chromatin. Annu. Rev. Biochem. 46: 931-954.

Kyrion, G., K. Liu, C. Liu, and A.J. Lustig. 1993. RAPl and telomere structure regulate telomere position effects in Saccharomyces cerevisiae. Genes \& Dev. 7: 1146-1159.

Lakhotia, S.C. and J. Jacob. 1974. EM autoradiographic studies on polytene nuclei of Drosophila melanogaster. Exp. Cell Res. 86: 253-263.

Levis, R.W., R. Ganesan, K. Houtchens, L.A. Tolar, and F. Sheen. 1993. Transposons in place of telomeric repeats at a Drosophila telomere. Cell 75: 1083-1093.

Lewis, E.B. 1950. The phenomenon of position effect. Adv. Genet. 3: 73-115.

Lima de Faria, A. and H. Jaworska. 1968. Late DNA synthesis in heterochromatin. Nature 217: 138-142.

Locke, J. 1993. Examination of DNA sequences undergoing chromatin conformation changes at a variegating breakpoint in Drosophila melanogaster. Genetica 92: 33-41.

Locke, J., M.A. Kotarski, and K.D. Tartof. 1988. Dosage-dependent modifiers of position effect variegation in Drosophila and a mass action model that explains their effects. Genetics 120: 181-198.

Lohe, A.R., A.J. Hilliker, and P.A. Roberts. 1993. Mapping simple repeated DNA sequences in heterochromatin of Drosophila melanogaster. Genetics 134: 1149-1174.
Lorentz, A., K. Ostermann, O. Fleck, and H. Schmidt. 1994. Switching gene swi6, involved in repression of silent matingtype loci in fission yeast, encodes a homologue of chromatinassociated proteins from Drosophila and mammals. Gene 143: 139-143.

Lu, Q., L.L. Wallrath, B.D. Allan, R.L. Glaser, J.T. Lis, and S.C.R. Elgin. 1992. Promoter sequences containing $(C T\rangle_{n} \cdot|G A|_{n}$ repeats is critical for the formation of the DNase I hypersensitive sites in the Drosophila hsp26 gene. J. Mol. Biol. 225: 985-998.

Lu, Q., L.L. Wallrath, and S.C.R. Elgin. 1993a. Using Drosophila P-element-mediated germ line transformation to examine chromatin structure and expression of in vitro-modified genes. Methods Mol. Genet. 1 333-357.

Lu, Q., L.L. Wallrath, H. Granok, and S.C.R. Elgin. 1993b. $(\mathrm{CT})_{\mathrm{n}} \cdot\left(\left.\mathrm{GA}\right|_{\mathrm{n}}\right.$ repeats and heat shock elements have distinct roles in chromatin structure and transcriptional activation of the Drosophila hsp26 gene. Mol. Cell. Biol. 13: 28022814.

Lu, Q., L.L. Wallrath, and S.C.R. Elgin. 1994. Nucleosome positioning and gene regulation. I. Cell. Biochem. 55: 83-92.

Lyon, M.F. 1961. Gene action in the X-chromosome of the mouse (Mus musculus L.). Nature 190: 372-373.

Miklos, G.L.G and J.N. Cotsell. 1990. Chromosome structure at interfaces between major chromatin types: alpha- and betaheterochromatin. BioEssays 12: 1-6.

Nimmo, E.R., G. Cranston, and R.C. Allshire. 1994. Telomereassociated chromosome breakage in fission yeast results in variegated expression of adjacent genes. EMBO /. 13: 38013811 .

Pardue, M.L. and W. Hennig. 1990. Heterochromatin: Junk or collectors item? Chromosoma 100: 3-7.

Paro, R. 1990. Imprinting a determined state into the chromatin of Drosophila. Trends. Genet. 6: 416-421.

Pimpinelli, S., G. Santini, and M. Gatti. 1976. Characterization of Drosophila heterochromatin. II C- and N-banding. Chromosoma 57: 377-386.

Polizzi, C. and L. Clarke. 1991. The chromatin structure of centromeres from fission yeast: Differentiation of the central core that correlates with function. $E M B O$ I. 112: 191-201.

Renauld, H., O.M. Aparicio, P.D. Zierath, B.L. Bilington, S.K. Chhablani, and D.E. Gottschling. 1993. Silent domains are assembled continuously from the telomere and are defined by promoter distance and strength, and by SIR3 dosage. Genes \&) Lev. 7: 1133-1145.

Reuter, G. and P. Spierer. 1992. Position effect variegation and chromatin proteins. BioEssays 14: 605-612.

Robertson, H.M, C.R. Preston, R.W. Phillis, D.M. JohnsonSchlitz, W.K. Benz, and W.R. Engels. 1988. A stable genomic source of $\mathrm{P}$ element transposase in Drosophila melanogaster. Genetics 118: 461-470.

Roseman, R.R., V. Pirrotta, and P.K. Geyer. 1993. The su(Hw) protein insulates expression of the Drosophila melanogaster white gene from chromosomal position-effects. EMBO $J$. 12: $435-442$.

Rougvie, A.E. and J.T. Lis. 1990. Postinitiation transcription control in Drosophila melanogaster. Mol. Cell. Biol. 10: $6041-6045$.

Rubin, G.M. 1977. Isolation of a telomeric DNA sequence from Drosophila melanogaster. Cold Spring Harbor Symp. Quant. Biol. 42: 1041-1046.

Rubin, G.M. and A.C. Spradling. 1982. Genetic transformation of Drosophila with transposable element vectors. Science 218: 348-353.

Rushlow, C.A., W. Bender, and A. Chovnick. 1984. Studies on the mechanism of heterochromatic position effect at the 
rosy locus of Drosophila melanogaster. Genetics 108: 603615 .

Russell, L.B. 1963. Mammalian X-chromosome action: Inactivation limited in spread and in region of origin. Science 140: $976-978$.

Sambrook, J., E.F. Fritsch, and T. Maniatis. 1989. Molecular cloning: A laboratory manual. Cold Spring Harbor Laboratory, Cold Spring Harbor, New York.

Sandell, L.L. and V.A. Zakian. 1992. Telomeric position effect in yeast. Trends Cell Biol. 2: 10-14.

Schlossherr, J., H. Eggert, R. Paro, S. Cremer, and R.S. Jack. 1994. Gene inactivation in Drosophila mediated by the Polycomb gene product or by position-effect variegation does not involve major changes in the accessibility of the chromatin fibre. Mol. \& Gen. Genet. 243: 45-3-462.

Shaffer, C.D., J.M. Wuller, and S.C.R. Elgin. 1994. Raising large quantities of Drosophila embryos for biochemical experiments. In Drosophila melanogaster: Practical uses in cell and molecular biology (ed. L.S.B. Goldstein and E.A. Fryberg), vol. 44, pp. 99-108. Academic Press, New York.

Sorsa, V. 1988. Structure of polytene chromosomes. In Polytene chromosomes in genetic research (ed. A. Wiseman), pp. 82106. Ellis Horwood Limited, West Sussex, UK.

Spofford, J.B. 1976. Position-effect variegation in Drosophila. In The genetics and biology of Drosophila (ed. M. Ashburner and E. Novitski), vol. 1, pp. 955-1018. Academic Press, New York.

Spradling, A.C. 1994. Position effect variegation and genomic instablilty. Cold Spring Harbor Symp. Quant. Bio. 59: 585596.

Spradling, A.C. and G.H. Karpen. 1990. Sixty years of mystery. Genetics 126: 779-784.

Spradling, A.C. and G.M. Rubin. 1983. The effects of chromosomal position on the expression of the Drosophila xanthine dehydrogenase gene. Cell 34: 47-57.

Steller, H. and V. Pirrotta. 1985. Repression of the Drosophila white gene under the control of the $h s p 70$ heat shock promoter. EMBO /. 4: 3765-3772.

Talbert, P.B., C.D.S. LeCiel, and S. Henikoff. 1994. Modification of the Drosophila heterochromatic mutation brown Dominant by linkage alterations. Genetics 136: 559-571.

Tartof, K.D., C. Hobbs, and M. Jones. 1984. A structural basis for variegation position effects. Cell 37: 869-878.

Thoma, F. 1992. Nucleosome positioning. Biochim. Biophys. Acta 1130: 1-19.

Thomas, G.H. and S.C.R. Elgin. 1988. Protein/DNA architecture of the DNase I hypersensitive region of the Drosophila hsp26 promoter. EMBO I. 7: 2191-2201.

Thompson, S.J., X. Ling, and M. Grunstein. 1994. Histone H3 amino terminaus is required for telomeric and silent mating locus repression in yeast. Nature 369: 245-247.

Tower, J., G. H. Karpen, N. Craig, and A.C. Spradling. 1993. Preferential transposition of Drosophila $\mathrm{P}$ elements to nearby chromosomal sites. Genetics 133: 347-359.

Tschiersch, B., A. Hofmann, V. Krauss, R. Dorn, G. Korge, and G. Reuter. 1994. The protein encoded by the Drosophila position-effect variegation suppressor gene Su(var)3-9 combines domains of antagonistic regulators of homeotic gene complexes. EMBO J. 13: 3822-3831.

Turner, B.M., L. Franchi, and H. Wallace. 1990. Islands of acetylated histone $\mathrm{H} 4$ in polytene chromosomes and their relationship to chromatin packaging and transcriptional activity. J. Cell Sci. 96: 335-346.

Turner, B.M., A.J. Birdley, and J.S. Lavender. 1992. Histone H4 isoforms acetylated at specific lysine residues define individual chromsomes and chromatin domains in Drosophlla polytene nuclei. Cell 69: 375-384.

Umbetova, G.H., E.S. Belyaeva, E.M. Baricheva, and I.F. Zhimulev. 1991. Cytogenetic and molecular aspects of position effect variegation in Drosophila IV. Underreplication of chromosomal material as a result of gene inactivation. Chromosoma 101: 55-61.

Valgeirsdottir, K., K.L. Traverse, and M.-L. Pardue. 1990. HeT DNA: A family of mosaic repeated sequences specific for heterochromatin in Drosophila melanogaster. Proc. Natl. Acad. Sci. 87: 7998-8002.

van Holde, K.E. 1989. Chromatin. Springer-Verlag, New York.

Verdin, E., P. Paras Jr., and C. Van Lint. 1993. Chromatin disruption in the promoter of human immunodeficiency virus type 1 during transcriptional activation. EMBO J. 12: 32493259 .

Wakimoto, B.T. and M.G. Hearn .1990. The effects of chromosome rearrangements on the expression of heterochromatic genes in chromosome 2L of Drosophila melangaster. Genetics 125: 141-154.

Wallrath, L.L., J.B. Burnett, and T.B. Friedman. 1990. Molecular characterization of the Drosophila melanogaster urate oxidase gene, an ecdysone-repressible gene expressed only in the Malpighian tubules. Mol. Cell. Biol. 10:5114-5127.

Wallrath, L.L., Q. Lu, H. Granok, and S.C.R. Elgin. 1994. Architectural variations of inducible eukaryotic promoters: Preset and remodeling chromatin structures. BioEssays 16: 1-6.

Wong, Y.C., P. O'Connell, M. Rosbash, and S.C.R. Elgin. 1981. DNase I hypersensitive sites of the chromatin for Drosophila melanogaster ribosomal protein 49 gene. Nucleic Acids Res. 9: 6749-6762.

Workman, J.L. and A.R. Buchman. 1993. Multiple functions of nucleosomes and regulatory factors in transcription. Trends Biochem. 18: 90-95.

Wright, W.E. and J.W. Shay. 1992. Telomere positional effects and the regulation of cellular senescence. Trends Genet. 8: $193-197$.

Wustman, G., J. Szidonya, H. Taubert, and G. Reuter. 1989. The genetics of position-effect variegation modifying loci in Drosophila melanogaster. Mol. \& Gen. Genet. 217: 520527.

Xiao, H. and J.T. Lis. 1988. Germline transformation used to define key features of heat-shock response elements. Science 239: 1139-1142.

Zhang, P and A.C. Spradling.1994. Insertional mutagenesis of Drosophila heterochromatin with single P-elements. Proc. Natl. Acad. Sci. 91: 3539-3543.

Zhimulev, I.F., E.S. Belyaeva, O.V. Formina, M.O. Protopopov, and V.N. Bolshakov. 1986. Cytogenetic and molecular aspects of position effect variegation in Drosophila melanogaster $\mathrm{I}$. Morphology and genetic activity of the $2 \mathrm{AB}$ region in chromosome rearrangement $T(1 ; 2) d^{\text {dor }}{ }^{\text {var }}$. Chromosoma 94: 492-502. 


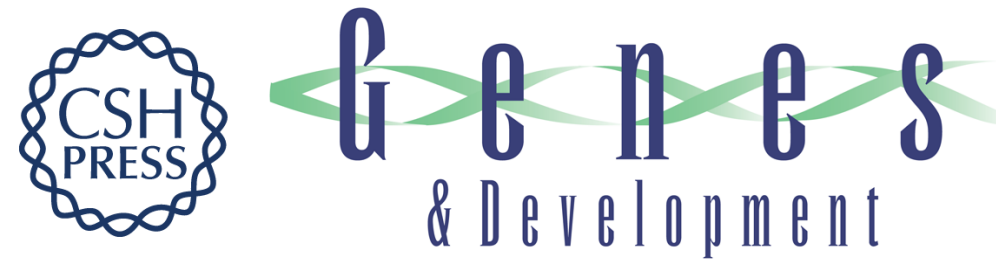

\section{Position effect variegation in Drosophila is associated with an altered chromatin structure.}

L L Wallrath and S C Elgin

Genes Dev. 1995, 9:

Access the most recent version at doi:10.1101/gad.9.10.1263

References This article cites 112 articles, 38 of which can be accessed free at:

http://genesdev.cshlp.org/content/9/10/1263.full.html\#ref-list-1

License

Email Alerting

Service

Receive free email alerts when new articles cite this article - sign up in the box at the top right corner of the article or click here.

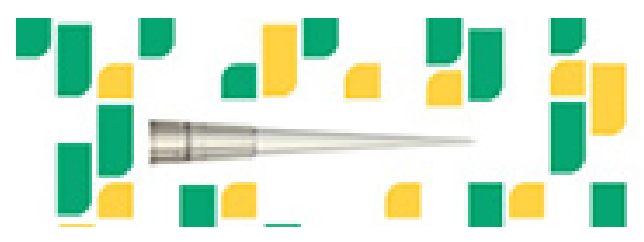

Focused on your science.

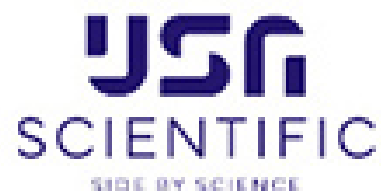

Copyright @ Cold Spring Harbor Laboratory Press 